\title{
Virological, immune and host genetics markers in the control of HIV infection
}

\author{
Beatriz Mothe $^{\mathrm{a}}$, Javier Ibarrondo ${ }^{\mathrm{a}}$, Anuska Llano ${ }^{\mathrm{a}}$ and Christian Brander ${ }^{\mathrm{a}, \mathrm{b}}$ \\ ${ }^{a}$ IrsiCaixa AIDS Research Institute-HIVACAT, Hospital Universitari Germans Trias i Pujol, 08916 Badalona, \\ Universitat Autònoma de Barcelona, Spain \\ ${ }^{\mathrm{b}}$ Institució Catalana de Recerca i Estudis Avançats (ICREA), Barcelona, Spain
}

\begin{abstract}
HIV infection, if left untreated, leads in most cases to the development of wide immune deterioration, opportunistic infections and eventually AIDS and death. The identification of individuals who despite persisting infection show no or few signs of HIV disease progression has spurred hopes that an effective HIV vaccine could be attainable. The design of such a vaccine will greatly depend on the precise definition of disease markers, host genetic and immune characteristics that mediate relative in vivo control of this virus. Accordingly, a number of viral factors and host genetic characteristics have been shown to play a crucial role in the control of HIV disease by delaying progression to AIDS or even preventing infection. There is also an improved understanding of humoral and cellular immune responses in terms of specificity, functional repertoire, longevity and tissue distribution and their ability to contain HIV replication. However, the definition of good immune correlates unequivocally and causally associated with protection or disease progression remains elusive. Here we review work on viral factors, host genetic markers and immunological determinants that have been identified in individuals with superior control of HIV infection or in subjects who remain uninfected despite frequent exposure to the viral pathogen.
\end{abstract}

Keywords: HIV-1, long-term non-progressors (LTNP), Elite Controllers (EC), Highly exposed persistently seronegatives (HEPS), CCR5, CTL, Innate immunity, HIV control, immune correlates, HLA allele frequency

\section{Introduction}

The AIDS pandemic is one of the greatest global health crises of our time. Since HIV was identified 25 years ago, 23 million people have died and 33 million more are living with HIV [1]. Despite advances in education, HIV prevention and improvements in access to antiretroviral drugs, the pandemic continues to outpace global efforts at prevention and control. According to the United Nations Development Program (UNDP), HIV has inflicted the "single greatest reversal in human development" in modern history [2].

AIDS vaccine research and development is of highest priority today and, at the same time, one of the biggest scientific challenges the immunology field faces. The enormous viral variability together with human host genetic diversity throughout the world are primary factors hampering the development of efficient strategies to control and prevent HIV infection and the design of potentially effective immune-based therapeutic inter- ventions and prophylactic vaccines. The recent failure in 2007 of a phase III trial of a prophylactic vaccine candidate further highlighted how far the field is still away from reliable markers of HIV control and how to best design an effective vaccine. Thus, an improved understanding of the immunopathogenesis of HIV infection and the role of host genetic markers and viral diversity in this control is urgently needed. However, it will likely not be sufficient to link certain more or less random markers with clinically well-established parameters of disease progression, such as plasma viral RNA levels and nadir CD4+ T-cell counts or CD4+ T-cell counts decline over time. Rather, specific markers that are directly mediating viral control need to be identified so that vaccine design is not misled by focusing on epiphenomena and functionally unlinked markers. This is certainly easier said than done as determinants of an effective viral control will likely need to be identified in multifactorial models that incorporate viral variability, environmental particularities (such as co-infections) and host genetics. 
Here we review the role of viral factors, host genetics markers and HIV specific immune responses in the control of HIV infection and their possibly underlying mechanisms. The determinants of viral attenuation, specific HLA class I and II alleles, certain polymorphisms in co-receptor genes and ligands, the specificity and functionality of virus-specific CD4+ and CD8+ T-cell responses, as well as new insights into factors of the innate immune response in HIV control are being discussed.

\section{Insights from studies in individuals with self-controlled viral replication and HEPS cohorts}

Infection with HIV leads to a devastating erosion of the immune system clinically characterized by a progressive rise in HIV viral load and decrease of the number of CD4+ T-cells. This decline in CD4+ T-cells heralds the progression to AIDS with its associated opportunistic infections and cancers and ultimately ends in death.

Among the HIV-infected population, several groups of individuals have been identified that remain clinically stable and free of any AIDS defining conditions for decades after infection in the absence of antiretroviral therapy [3]. These individuals (estimated to be 5$8 \%$ out of the total HIV-infected population) have been referred to as long term survivors (LTS) or long-term non-progressors (LTNP) and are generally able to control viral replication to low levels - plasma RNA levels $<2,000$ copies/ml (or $<5,000-10,000$ copies/ml, depending on arbitrary cut-offs decided upon by different investigators) and to maintain normal CD4+ T-cell counts over time with a reduced rate of CD4+ T-cell loss ( $18 \mathrm{cells} / \mu 1 /$ year $)$ compared to that in normal progressors (around 60 cells/ $\mu 1 /$ year) [4]. A subset of such LTNP is able to maintain undetectable plasma viral loads for extensive period of times and is known as elite controllers (EC). The clinical and scientific interest in such individuals is great as they may indeed hold the key of spontaneous control of HIV infection. Current efforts have allowed for the establishment of large international cohorts of controllers and elite-controllers and an intensive search for host genetic, virological as well as immunological markers of HIV control is ongoing in these subjects.

Some recent work on elite controllers (estimated to represent less than $1 \%$ of the HIV infected population) has shown wide heterogeneity in the immunological and clinical course of HIV infection despite certain similarities in genetic determinants [5], again suggesting that HIV control needs to be seen in a context that integrates host genetics, immune function as well as virological diversity. Nevertheless, these and earlier analyses have directly allowed to identify a number of properties of the immune response to HIV (specificity, T cell polyfunctionality), as well as host genetic markers (mainly HLA class I alleles) that are strongly associated with disease control and which will prove helpful in the quest of developing a broadly applicable HIV vaccine.

Similarly, highly Exposed Persistently Seronegatives (HEPS) individuals, such as some commercial sex workers or discordant couples who are multiply exposed to HIV yet remain uninfected, may also provide important clues into potential mechanisms of HIV control and even prevention of infection [6,7]. However, these studies need to always be well documented for real exposure to HIV, even more so now that studies in discordant couples sometimes include HAART treated subjects which put the seronegative partner at clearly reduced risk of HIV acquisition. Some recent studies have identified genetic polymorphisms in the SDF1 gene, specific CD8+ T cell responses and IgA production as factors associated with a reduced risk of HIV acquisition in these groups [8-12]. However, T cell response rates and antibody production have not emerged consistently in all studies as potentially protective [13, 14] and further studies are needed to clarify these findings. In addition, immune analyses conducted to identify potentially protective immune responses need to be based on sensitive but specific assays and stringent cutoffs [15]. Given these considerations, it can reasonably be expected that future analyses on HEPS may provide further valuable information.

\section{Viral determinants in control of HIV-infection}

While individuals with apparently effective control of HIV infection (LTNP, elite controllers) have been studied exhaustively for virus-specific immune responses, less is known about potential virological determinants that could be driving the observed control. A number of studies have identified single individuals or small cohorts (such as the Sydney Blood Bank Cohort-SBBC- a unique collection of individuals infected with an attenuated HIV-1 virus from a common donor) that harbor partially defective viruses that seem to have a decreased replication competency. Others have also 
been able to isolate virus with impaired replicative capacity from PBMC cultures generated from LTNP, supporting the hypothesis that primary infection by 'attenuated virus strains' with slow replication kinetics may facilitate control of viremia [16]. This is not only of relevance to the replication fitness of potentially partly defective viruses as it could also reduce the kinetics of viral evolution and CD4 $+\mathrm{T}$ cell depletion over prolonged period of time.

A certain 'acquired' degree of attenuation in terms of impaired replicative capacity could be partially induced by antiretroviral therapy, as individuals who were efficiently treated for long periods of time showed a prolonged delay in restoration of pretreatment viral diversity after therapy interruption (STI). This suggested that punctuated antiretroviral therapy may cause a considerable evolutionary bottleneck leading to the emergence of viral populations with overall reduced viral fitness [17]. However, it could also reflect improved immune competence and at least partial immune restoration after prolonged treatment periods, which could on its own impact viral repopulation dynamics.

Aside from treatment-induced viral variants, several viral genetic defects and polymorphisms that impair replicative capacity have been implicated in mediating relative viral control. Viral genomes carrying deletions or inactivating variants in the nef gene or in the overlap of nef and the $\mathrm{U} 3$ region of the long terminal repeat (LTR) were among the very first viral defects associated with control. These cases were identified in 1995 in a group of 6 individuals from the SBBC cohort who had become infected after obtaining blood transfusions from the same HIV-infected blood donor but remained free of HIV-related disease [18]. Although still unclear, one potential underlying mechanism suggested for the beneficial effects of this nef deletion is that Nef is no longer available to down-regulate HLA class I molecules and infected cells thus would be more readily recognized by HIV-specific CD8 + T cells [19]. However, longitudinal analysis of viral evolution of the nef/LTR sequences over time in the SBBC cohort, were unable to fully explain mechanisms that could have contributed to slow progression of HIV disease in 2 (out of the 6) individuals of the cohort, suggesting that nef gene deletions are not necessarily mediating life-long protection from disease progression. Thus, other viral and/or host factors plus immune pressure was likely contributing to the long-term control in these individuals [20].

Aside from Nef-mediated effects, other mutations in structural proteins have been associated with slower disease progression as well. These include unusual, difficult-to-revert polymorphisms and 1-2 amino acids deletion in gp41 and Gag or a four amino acids insertion in Vpu among others [21]. In addition, replication defective strains have been identified when constructing viral clones with mutations at the rev activation domain, which were seen more frequently in controller individuals than in subjects with regular HIV disease progression [22]. In addition, to these mutations of unknown origin in terms of specific selective force (apart from reduced replication capacity), viral mutations evolving under strong immune selection pressure have been show to lead to reduced viral replication (see below).

Despite these reported cases of reduced replicative viruses and slower disease progression, the frequency and contribution of such defects on the maintenance of undetectable viremia is not well established. In particular, conflicting data exists partly due to the fact that the identification of such attenuated virus strains in vivo is limited to small numbers of subjects and that sequence analyses have often been based on analyzing cellular proviral DNA, thus possibly also including some level of grave-yard sequences. Today, with more sensitive assays, some elite controllers have been shown to have persistent viral replication detectable in plasma at levels below 50 copies/ml [23]. In addition, a recent report by Miura et al for instance did not reveal any gross genetic defects in HIV-1 coding gene sequences derived from plasma viral RNA from a large cohort of elite controllers [24]. This observation suggests that active viral suppression by the immune system rather than shared viral genetic defects or polymorphisms is driving viral control in HIV controllers. This conclusion is also in line with work on accessory genes from HIV controllers, where replication-competent viruses from CD4+ T-cell co-culture supernatants were analyzed and did not reveal any consistent defects in either vpr or vif genes [25].

\section{Impact of host genetics on in vivo HIV control}

An extensive number of host genetic markers have been identified over the last 20 years that are associated with either rapid or slow HIV disease progression or with protection from infection. Many older studies however were carried out using single gene approaches with small number of samples and the genetic associations found were not always confirmed in subsequent functional studies. Thanks to the advances of the $\mathrm{Hu}-$ mane Genome Project, the use of whole-genome as- 
sociation scans, and the establishment of international consortia such as CHAVI, EuroCHAVI or the HIV International Controllers consortium, it has been possible to uncover certain genetic factors that might play a relevant role in the control of HIV. This availability of large samples number and the possibility to sequence 650,000 single-nucleotide polymorphisms within the human genome should further enhance studies examining the contribution of multiple genetic factors [26]. However, unlike studies on genetic markers associated with for instance autoimmune diseases, the search for host genetic polymorphisms in HIV infection also needs to take into consideration the viral diversity in regions of different host genetics/ethnicities. An earlier report on the effect of a single genetic (HLA) marker and viral evolution has recently been confirmed in a massive international effort, demonstrating the inter-relationship between host genetics and viral evolution $[27,28]$. These findings highlight that viral diversity is likely be shaped by differences in the frequency of different host genetic markers and, based on viral evolution, can lead to opposite effects of a specific genetic marker on HIV disease control [27]. Thus, whole human genome approaches are severely complicated by viral diversity in different host ethnicities making comparisons across different clades of HIV and various geographically distinct human populations difficult. This consideration also points to the possibility that different clades of HIV may possess inherently different replication fitness and may drive disease development at variable levels, as recently considered as a possibly contributing factor in a case of severe acute HIV infection [29].

\section{Association of HLA polymorphisms with HIV disease outcome}

Many host genetic polymorphisms associated with levels of disease control involve genes encoding for receptors for viral entry and molecules expressed on the surface of cells of the innate or acquired immune system, such as HLA, CCR5 and KIR receptors. Moreover, it seems that in some cases their potential protective influence might have a cumulative effect as seen for the synergic effect of some KIR receptors and HLA-B complexes [30]. Likely the most robust analyses have focused on the HLA genes and their polymorphisms. The HLA class genes form highly polymorphic loci in the Major Histocompatibility Complex (MHC) located in the short arm of chromosome 6 and encode for cel- lular surface molecules that present foreign antigenic epitopes to T lymphocytes. There are two groups of HLA molecules including HLA class I and HLA class II antigens. The HLA class I molecules are divided into HLA-A, HLA-B, HLA-C all of which bind peptides derived from intracellularly processed proteins and present them to CD8 + cytotoxic T-cell lymphocytes (CTL). Among these, the HLA-B alleles, while most diverse (more than 1,000 HLA-B alleles have been identified to date) have also been shown to carry the bulk of the anti-viral $\mathrm{T}$ cell immune response in HIV infection [31]. Accordingly, the number of welldefined HLA-B restricted epitopes exceeds the number of defined epitopes restricted by HLA-A and, particularly, HLA-C alleles. However, especially the HLA-C alleles are currently under more intensive investigation as larger HIV infected cohorts with more complete and high-resolution HLA-C typing have become available.

HLA alleles are grouped into 9 supertypes based on their structure, peptide-binding motif, epitope representation and sequence similarity [32,33]. Particularly alleles included in the HLA-B7 (B*5101, B81), HLA-B27 (HLA-B27, B*1503) and HLA-B58 supertypes (HLA-B57, B*5801, B*1516, B*1517) have been associated with improved or impaired levels of HIV control. Of note, almost all the alleles in the HLA-B58 supertype appear to mediate superior control of HIV infection [34]; with the exception being the HLA-B*5802 allele, which is highly prevalent in South Africa and which is associated with elevated median viral loads [35]. The reasons how subtle changes in the HLA sequence (HLA-B*5802 only differs in three amino acids from the "good" HLA-B*5801 allele) can so profoundly affect HIV disease outcome are still unclear and are not in all cases simply attributable to different CTL epitope repertoires presented on these alleles $[35,36]$. The fact that this allele, as well as the HLA$\mathrm{B} * 1503$ allele are present at high frequency and are both associated with higher viral loads in HIV infected individuals (HLA-B*1503 is a "good" allele in the North American population where it is rare; ref [27]) is in line with earlier reports that found an advantage of expressing rare HLA supertype alleles in controlling HIV [37].

In addition to HLA allele frequency, the homocygous expression of individual HLA alleles has been associated with reduced viral control. This heterozygote advantage has been widely observed in several cohorts, including Caucasian and non-Caucasian populations [38, 39] and has been reproduced in Hepatitis $C$ infection for which HLA-associated markers of viral clearance 
and virus control have been identified as well [40]. Furthermore, the effects of particular HLA supertypes or of individual alleles have also been reported to provide the basis for immunologically mediated resistance to infection $[41,42]$. It will be interesting to confirm the potential protective effects of such alleles in additional cohorts with variable allele frequencies and to assess other mechanisms and markers present in genetic linkage to these alleles that may possibly be involved to at least some levels in protection from HIV infection [43].

Associations between HIV control and specific polymorphisms in the HLA class II loci have been less welldefined, maybe reflecting a possibly only indirect antiviral effect of HLA class II restricted CD4+ T cells. Nevertheless, some cohort-based studies have reported that DRB1*13 allele expression is associated with partial protection from HIV disease progression, although this has not consistently been observed [44]. The DRB1*13/DRQ1*06 haplotype has also been found at increased frequency in individuals who were treated early in HIV infection and who maintained virus suppression after treatment interruption [45]. Furthermore, a protective role of DQB $1 * 06$ alleles, irrespective of their DR haplotype co-expression, has been identified [46]. While the HLA class II associations have not produced as strong markers as HLA class I analyses, the representative studies given above highlight the importance to further explore the contribution of the specific $\mathrm{CD} 4+\mathrm{T}$ cell responses and their genetic basis in the control of HIV.

\section{Specific HLA class I B alleles associated with variable levels of HIV control}

HLA-B*5701 and, to a lesser extent HLA-B27 are HLA-B alleles overrepresented in North American and European cohorts of LTNP and EC individuals [26,38, $39,47,48$ ] and reviewed in [49]). Similarly, the HLA$\mathrm{B} * 5703$ allele (which is the prevalent B57 subtype in Africans) is also significantly enriched among African subjects that control HIV replication $[31,50]$. These associations are further supported by survival analyses of HLA-B57 and HLA-B27 expressing individuals [51]. How these alleles mediate their beneficial effect has however not been entirely clear, although in the case of HLA-B27 and HLA-B57 compelling evidence suggests it may be due to their presentation of multiple immunodominant epitopes located in HIV Gag and reverse transcriptase $[5,52,53]$. The broad epitope repertoire and the wide cross-recognition of epitope vari- ants presented by HLA-B57 suggest that effective viral escape from HLA-B57 restricted CTL responses may be difficult to achieve. Of note, HLA-B*5701 is in strong linkage disequilibrium with the polymorphism located in the HLA complex P5 gene (HCP5), located $100 \mathrm{~kb}$ centromeric from the HLA-B locus and who has been identified as a protective marker of HIV infection, independent HLA-B57 expression [26]. However, the mechanistic explanation of this protective effect remains elusive and probably is a result of a combined haplotypic effect with HLA-B*5701. This is also in agreement with recent studies showing significant fitness cost of HIV escape variants that affect HLA-B57 restricted CTL epitopes [54]. Similar results have recently also been reported for CTL responses targeting HLA-B13 restricted epitopes, which support the notion that the nature of the presented epitope, more than the restricting HLA molecule allele may determine the beneficial effects of a specific HLA allele [27,55]. However, evolutionarily closely related alleles with subtle sequence differences and comparable binding motifs but associated with opposite rates of HIV disease progression also indicate that the presenting HLA molecule may have a modulating effect on the effectiveness of the restricted $\mathrm{T}$ cell response.

Analogous to the HLA-B58 and -B13 alleles above, the protective effect of HLA-B27 allele is also thought to be due to its restriction of an immunodominant CTL response to a conserved HIV epitope located in p24 Gag. This 10mer epitope sequence contains the arginine residue at position 264 of HIV Gag which, once mutated weakens the epitope binding to HLA-B27 [56]. However, the classical mutation to lysine has detrimental effects on viral replication capacity and requires a complex series of compensatory mutations in partly distant sites in Gag to restore viral fitness [57-59]. Thus, the mutation is less likely to revert and to restore full replication fitness and individuals with the escape mutation may still present with lower viral loads than the rest of the population.

Apart from HLA alleles that mediate relative protection from HIV disease progression, a number of alleles have been identified that are linked to accelerated disease courses. Among these, the HLA-B35/Cw04 haplotype has been consistently found at increased levels in individuals with rapid progression to AIDS [38]. Subsequent studies revealed different peptide-binding specificities for the various HLA-B35 subtypes, which prompted their discrimination into Py and Px alleles, respectively [36]. Accelerated HIV disease progression has been associated with the HLA-B35 Px (HLA- 
$\mathrm{B} * 3502 / 3503 / 3504)$ alleles but not Py alleles $(\mathrm{B} * 3501)$. This could explain why HLA-B35 associations were not observed in African-Americans as this ethnic group often expresses HLA-B35-Py alleles. It has also been suggested that the HLA-Cw04 association with rapid disease progression was due to its linkage disequilibrium with HLA-B35-Px alleles rather than exerting a deleterious effect by itself [36].

Aside from HLA linkage disequilibrium and other polymorphisms in the MHC region, the potentially synergistic effects of specific HLA type and NK inhibitory receptor (KIR) have recently obtained much attention. KIR receptors are polymorphic receptors that interact with HLA class I molecules and regulate the NK activity, either by mediating activating or inhibitory signals. A number of studies have associated the expression of specific HLA and KIR combinations with different diseases, such as cervical neoplasia and infectious diseases, including HIV [30,60-62]. The insight into potential mechanisms of these favorable combinations is most advanced in the case of HLA-B/KIR allele combinations. HLA-B molecules contain one of two mutually exclusive serological epitopes, Bw4 and Bw6, which differ by five amino acids spanning positions 77-83 of the HLA-B heavy chain, including the crucial Isoleucine residue at position 80 [63]. HLABw4- but not HLA-Bw6-molecules have been considered ligands for KIR3DL1 and possibly KIR3DS1 [62, $64,65]$. In a proportional hazard model that included all known genetic predictors of HIV progression, coexpression of KIR3DS1 and HLA-Bw4 was found to be an independent predictor of decreased time to AIDS. Interestingly, this beneficial effected was observed despite the fact that KIR3DS1 alone in the absence of its HLA ligand was associated with more rapid disease progression. Thus, the findings highlight the potential for KIR/HLA interactions to be important independent predictors of HIV progression and may help shed light on the relative contribution of these interactions compared to HLA-restricted CTL activity $[62,66]$.

\section{Non-MHC encoded genetic markers of HIV control}

Although the CD4 antigen is the main receptor for HIV entry into susceptible cells, effective viral infection requires the presence of one of two major coreceptors, referred to as CCR5 and CXCR4, respectively. These two co-receptors belong to the superfamily of 7-transmembrane G-protein-coupled chemokine receptors and determine viral tropism, allowing for the differentiation of R5, X4 or R5/X4 viruses that can use either one or both of these receptors $[67,68]$.

Chemokines are a superfamily of small molecules $(8-15 \mathrm{kDa})$ that exert many roles in inflammatory and in homeostatic immune processes $[69,70]$. They are divided into four subfamilies based on the structural cysteine motif located in the amino-terminus of the mature protein (CXC, $\mathrm{CC}, \mathrm{CX}_{3} \mathrm{C}$ and $\mathrm{C}$ chemokines) and their receptor usage shows a considerable level of redundancy [71]. The chemokine Regulated on Activation Normal T-cell Expressed and Secreted (RANTES or CCL5), Macrophage Inflammatory Protein-1 $\alpha$ (MIP$1 \alpha$ or CCL3) and $1 \beta$ (MIP- $1 \beta$ or CCL4), were first identified as natural ligands for the CCR5 receptor and were subsequently shown to be potent inhibitors of R5 viruses in vitro. The natural ligand of CXCR4 is Stromal Cell Derived Factor-1 (SDF-1 or CXCL4), which also possesses potent inhibitor function of $\mathrm{X} 4$ viruses in vitro [72-74]. Other chemokine receptors that can act as HIV co-receptors have been described, including CCR3, CCR2b and CCR8 [75].

Shortly after their identification as crucial HIV co-receptors, genetic polymorphisms in the various chemokine receptors were reported. In particular, a 32 base pair deletion in the CCR5 gene (CCR5- $\Delta 32)$ was identified that generates a non-functional protein that is not expressed on the cell surface. The homocygous expression of the CCR5- $\Delta 32$ variant provides in vivo resistance to infection by $\mathrm{R} 5 \mathrm{HIV}$ isolates. These observations were made in different cohorts of men who have sex with men and hemophiliacs with documented exposure to HIV. When present in a single copy only, the heterocygous expression of the wildtype CCR5 receptor was found to be sufficient to enable infection, although the lower levels of CCR5 on the cell surface were associated with reduced viral replication and a delayed onset of AIDS [76-79]. Spurred by the effects of heterocygous expression of CCR5- $\Delta 32$, mutations in the promoter region of CCR5 were identified that are also associated with altered transmission or delayed disease progression, although to a lesser extent than the CCR5- $\Delta 32$ mutation [80,81].

In addition to the CCR5- $\Delta 32$ mutation, the V64I substitution in the CCR2A protein sequence (CCR2V64I) has also been found to delay HIV disease progression; however without preventing HIV transmission. Intriguingly, CCR2 is rarely used as a co-receptor in HIV infection and its impact on global epidemic is unclear. Furthermore, it has been demonstrated that the CCR2-V64I allele is in strong linkage disequilibri- 
um with a point mutation in the CCR5 regulatory region [82]. Together with CCR5 mutations, approximately $29 \%$ of LTNP phenotypes in large cohorts have been estimated to be due to a mutant genotype for CCR2 or CCR5 [83]. Interestingly though, relative protection against AIDS provided by CCR $5-\Delta 32$ heterocygosity appears to be continuous during HIV disease over time, whereas the protective effects of the CCR2-64I variant was most pronounced in early infection [84].

The identification of CCR5 and CCR2 as crucial molecules for HIV-infection has also offered new treatment targets to inhibit viral replication and CCR5-based HIV entry-inhibitors have been developed are now part of effective rescue treatment strategies $[85,86]$. More recently, a single case of stem-cell transplantation from an homocygous CCR5- $\Delta 32$ donor to an HIV-infected individual with acute myeloid leukemia showed no signs of rebounding viremia in plasma, bone marrow or rectal mucosa 20 months post-transplantation and in the absence of antiretroviral treatment. This is even more surprising given that minor X4-variants were identified in the pre-transplantation viral population, giving rise to a number of questions on how viral populations with different cell tropism are controlled in vivo [87].

Polymorphisms involving other chemokine receptors and/or other chemokine receptor ligands have been identified as well. Especially, plasma levels of RANTES, which can significantly vary among healthy individuals, were found to be modulated by two single nucleotide polymorphisms in the RANTES gene promoter region. These changes have also been associated with delayed progression of HIV disease and experimental over-expression and increased promotor activity of RANTES functionally link the polymorphisms with reduced HIV replication capacity as a consequence of increased RANTES production [88-90]. Similarly, a genetic variant consisting of a transition (G-A) in the 3'untranslated region of the SDF-1 gene (SDF-1 3'A) has also been associated with a delay in AIDS onset when present as homocygous variant. Its underlying mechanism and effect on $\mathrm{X} 4$ viral populations in vivo is however not well understood [91-94]. Noteworthy, no mutations in the CXCR4 receptor gene have been proposed as markers of relative HIV control, probably because CXCR4 and SDF-1 are essential at embryonic development stages and, consequently, such mutations might be potentially lethal [95].

A genetic determinant that has recently been associated with rate of HIV disease progression is the copy number of the chemokine gene CCL3L1 (MIP-1 $\alpha$ ). Individuals with higher CCL3L1 copy numbers than the population race-adjusted average showed lower steadystate viral load; suggesting an increased rate of HIV disease progression in subjects with lower CCL3L1 copy number [96].

Finally, several polymorphisms in the DC-SIGN (dendritic cell specific intracellular adhesion molecule -3-grabbing nonintegrin, i.e. CD209) promoter have been found to be linked to an increase or decrease in susceptibility to HIV infection, particularly also in parenterally acquired HIV infection [97]. As DC-SIGN has also been associated with tuberculosis infection and disease outcome, studies such as a recent one in an Indian population, may help employing DC-SIGN based strategies for the combined fight against these two major human pathogens [98].

\section{Immune markers in the relative control of HIV infection}

An extensive amount of data indicates a potentially crucial role of HIV-specific cellular and humoral immune responses in the in vivo control of viral replication and HIV disease progression. As discussed above, a number of host genetic markers have been identified, particularly specific HLA class I alleles, suggesting an important contribution of the HLA class I restricted CD8 + T-cell immunity in virus control. Despite an increasingly more detailed understanding of the interplay between host immunity, viral evolution and the impact on viral control, clearly defined immune correlates of controlled HIV infection remain elusive. As a consequence, effective vaccine design is still hampered by the availability of well-defined immune parameters that actively mediate in vivo viral control. While much of the current investigations focus on the detailed characterization of individuals with exceptional ability to control their virus, it is important to notice that the immune markers associated with this control can often be biased towards subjects expressing specific host genetics and are thus not necessarily translatable to the general population. Nevertheless, a number of specific characteristics of the host immunity against HIV that have been identified clearly extend beyond these limitations and will provide important guidance to vaccine development and offer new immune-based therapeutic treatment options.

\section{HIV disease markers associated with virus-specific cellular and humoral immunity}

It is generally believed that the cytotoxic T cell (CTL) 
immune response contributes strongly to the in vivo control of viral control. Virus-specific CTL responses have been temporally associated with the initial decline in plasma viremia after acute HIV infection and are thought to determine viral set point in chronic stages of infection $[99,100]$. This is supported by studies in the SIV macaque model, where transient depletion of the total CD8 + T-cell population in controller animals resulted in 100- to 10,000-fold increases in viremia and where the re-establishment of the $\mathrm{CD} 8{ }^{+} \mathrm{T}$-cell populations restored the ability of these animals to control SIV replication [101,102]. Further support for an important role of virus-specific CTL in HIV control stems from older studies conducted when tetramer technology became first available in the late 1990ties [103]. The use of such tetramer complexes allowed for the direct ex vivo visualization of epitope-specific CTL populations and analysis of specific responses against defined epitopes, without prior in vitro expansion and modulation of epitope-specific T cells [104]. Initial analyses using SL9 (SLYNTVATL, HIV Gag p17) specific tetramers, revealed a significant inverse correlation between SL9-specific CTL frequency and plasma RNA viral loads [105]. These analyses were however only based on a limited number of SL9-responding subjects and did not take into consideration the possibly impaired functionality of tetramer-specific T cells. Not surprisingly, the SL9 association with HIV control were not confirmed in studies that used in vitro expanded $\mathrm{T}$ cells, possibly due to the differential ability of such cells to expand in vitro [106]. Since these earlier studies, novel assays, including the IFN- $\gamma$ based ELISpot assay and in vitro inhibition assays first developed by Yang et al. [107,108] provide additional tools to assess direct ex vivo T cell activity and functionality [109,110]. These analyses further support the relevance of HIV specific T cells in HIV control, although in many studies, the precise phenotypic and functional markers of these virus-specific T-cell responses attributed to viral control may reflect the effects rather then the cause of otherwise controlled HIV infection. Dissecting these two possibilities and assigning unambiguously causality to specific immune markers and $\mathrm{T}$ cell specificities remains one of the currently biggest challenges in defining functionally relevant immune correlates of HIV control.

Over the years, an number of studies have correlated strong and broad HIV-specific T-cell responses with the delayed progression to AIDS and vaccine success is oftentimes subjected to a quantification of the total breadth and magnitude of induced responses. While a detail characterization of vaccine-induced responses will always need to be conducted, it is also clear from a growing number of reports [111] that total virus specific immunity is not necessarily the best measure of in vivo immune control of $\mathrm{HIV}$ and that more detailed analyses of these responses are needed. Indeed, reanalyses of earlier total-virus specific CTL data suggest that T-cell responses preferentially targeting Gag or other highly conserved epitopes are most relevant specificities for the enhanced antiviral efficacy of Tcells seen in those individuals $[109,112]$. On the other hand, CTL responses against Env or accessory and regulatory proteins have been shown to have the opposite effect, and are directly correlated with elevated viral load [50]. These findings are in line with more recent studies in clade B as well as clade $\mathrm{C}$ infection and analyses that either assessed total viral immunity in peptide pools rather than individual peptide preparations or that focused on responses restricted by specific individual HLA alleles only [50,52,113-117].

However and despite strong associations between Gag-specific T cell immunity and relative HIV control, the causative relationship between the observed response patterns and viral control is still outstanding. Plausible explanations for how dominant Gag specific cytotoxic T-cells could mediate relative virus control stem from the ability of certain HLA class I molecules such as HLA-B57 to present a broad number of HIV Gag peptides and to induce high-magnitude CD8+ Tcell responses in early infection [52,113]. In addition, rapid re-presentation of epitopes derived from the Gag proteins contained in the incoming, infecting virus particles (possibly within less than $2 \mathrm{hr}$ after infection) may provide Gag-specific T cells with a decisive advantage to eliminate infected cells before massive virus production has been initiated [118]. However, not all dominant Gag-protein specific responses may be equally effective and comparative studies in clade $\mathrm{C}$ and $\mathrm{B}$ infection have identified subdominant $\mathrm{Gag}$ responses as well as responses outside of Gag as crucial components in relative virus control [27]. The important role of subdominant responses has also been confirmed in studies in the SIV macaque model and is also supported by the detection of subdominant CTL responses in groups of HEPS [11,101].

Apart from CTL specificity, the in vivo antiviral efficacy of HIV-specific CD8+ T-cell immunity has also been tightly linked to the functional competence of these responses. In particular, proliferative capacity with high perforin expression and secretion of multiple cytokines such as IFN- $\gamma$, IL-2, TNF- $\alpha$, MIP-1b and/or 
CD107a surface expression after antigen contact characterize the responses seen in LTNP [119,120]. In addition to polyfunctionality, the avidity of virus-specific T-cell responses is also considered a potentially important measure of an effective immune response and has been shown in HCV infection, to be associated with viral clearance and higher levels of cross-variant recognition $[121,122]$. Thus, the quality of the CD8+ T-cell response to HIV serves as a better marker of controlled infection than the quantity (i.e. breadth and magnitude) of these responses. In addition, a HLA$\mathrm{DR}+, \mathrm{CD} 38$ - activation CD8+ T-cell phenotype was more frequently found among virus-specific T-cells in HIV controllers than in non-controllers and may represent a $\mathrm{T}$ cell population with superior ability to expand upon exposure to antigen and capacity to exert effector functions [110]. Whether full-differentiation into CCR7-/CD45- effector cells and broad functional CTL is only a hallmark of controlled HIV infection in the peripheral PBMC compartment or also extends to CTL in gut-associated lymphoid tissue -where massive initial depletion of CD4+ T-cells occurs- remains an open question. Nevertheless, a rapidly growing set of reports dealing with the emergence and accumulation of CTL escape mutations under appropriate CTL pressure, the transmission of "escaped" variants, implications of fitness costs incurred by CTL escape mutations and the global adaptation of HIV to HLA class I polymorphisms further document the crucial role that HIV-specific CTL overall play in the control of HIV infection [28,54,58,123-130].

An additional factor for an effective CD8+ T-cell response includes the presence and function of $\mathrm{CD} 4+$ 'helper' T-cells. HIV-specific CD4+ T-cell population have been shown to be required for long-term maintenance of antigen-specific CD8+ memory T-cells, both in the human setting as well as in the monkey model [101,131-133]. The relevance for functional CD4+ T-cell help in the maintenance of effective CTL populations has recently also been reported for viral infections other than HIV, including EBV and CMV infections $[134,135]$. The potential importance of virusspecific $\mathrm{T}$ helper cell activity is further highlighted by studies that have associated the presence of gp41specific antibodies with CD4+ T-cell responses to Gagp24 [136,137]. Regardless of the well-documented anti-viral effects of neutralizing Ab responses [138] general antibody-responses have not emerged as strong markers of HIV control. Some of the existing data have been inconsistent as some studies have associated higher titers of heterologous nAb in LTNP whereas more recent studies indicate the presence of lower Nab activity among elite controllers [5,16,139]. It will be interesting to investigate whether possible residual viral replication in the former group of patients may drive additional $\mathrm{Ab}$ production or whether additional, unaccounted factor and assay differences are responsible for the observed differences.

\section{Innate immunity}

During primary HIV infection, there is a massive destruction of the CD4+ T-cell population in the gutassociated lymphoid tissue (GALT) impairing local cellular immunity at mucosal sites and causing translocation of microbial products which in turn contributes to a deleterious persistent inflammation [140,141,143]. The potential damaging effects of chronic inflammation by continuous bacterial translocation are also highlighted by similar studies in HCV infection, where it has been implicated in the progression to advanced stages of cirrhosis [144]. Most importantly however, the massive depletion of CD4+ T-cells, general inflammation and immune activation occur at times when the adaptive immune system has not mounted an effective immune response yet. As mentioned above, some markers associated with the innate immune system, particularly KIR and Toll-like receptors (TLR) have been associated with variable levels of HIV control in these early stages of infection. As such, recent host genetic studies indicate that individuals co-expressing KIR3DS1 and HLA-Bw4-80I (family of HLA alleles that presumably bind to KIR3DS1 and activate NK cells) have lower viral loads and show a reduced risk of progression to AIDS [62,145]. In addition, polymorphisms in toll-like receptor 9, which mediates innate immune response against DNA motifs common in bacteria and viruses, have recently been shown to impact clinical outcomes as well [146]. However, significant functional data supporting the innate immunity and its linkage to disease pathogenesis is still scarce and needs to be further explored. In addition, extensive cohorts of individuals captured in earliest period of acute HIV infection will need to be comprehensively studied to assess the impact of these markers on initial peak viremia and the level of CD4+ T-cell depletion. However, the recent identification of immune memory mediated by NK cell populations may offer novel approaches for preventative and therapeutic interventions in HIV infection [147].

\section{Conclusions and implications for vaccine design}

Control of viral replication in HIV infection is a mul- 
tifactorial process. Polyfunctional CD8+ T-cell immunity against particular viral proteins along with virusreactive CD4+ T-cell help have been most consistently implicated in modulating HIV infection in vivo. Viral factors such as specific mutations often emerging as a consequence of immune selection pressure and entire gene segment deletions have also been associated with reduced viral burden and slower progression of HIV disease. In addition, specific host genetic markers, particularly HLA, has been most compellingly linked to relative control of HIV replication. While such host genetic markers may provide great help in understanding the (immune)-pathology of HIV, they will likely not be directly informative for HIV vaccine development. However, they can guide vaccine immunogen design, although care needs to be taken that such immunogen design is not overly guided by observations made in individuals with favourable host genetics. To avoid the resulting vaccine product to be tailored unreasonably strongly towards individuals with beneficial genetics, subjects who do not express these markers yet control HIV on their own will be most informative. In addition, while immune parameters that could mediate sterilizing immunity, i.e. resistance to infection, still need to be defined, the development of vaccines that are able to induce partial in vivo control, albeit not prevent infection, would have significant impact on individual health by slowing HIV disease progression and would help to contain the HIV pandemic by reducing transmission rates.

In this regard, the early assessments of vaccine success in phase I and phase II trials will be based on immune read-outs, rather than prevention of infection (which would be the central end-point in a phase IIb/III trial). Thus, the definition of precise immune correlates of controlled HIV infection is crucial since vaccine induced responses will be compared to these parameters. If their definition is flawed or represents epiphenomena of otherwise controlled HIV infection, valuable vaccine candidates may be discarded prematurely. Together with immune parameters of controlled infection, the identification of host genetic markers may in the future facilitate the design of gene therapy approaches that would try to either block expression of unfavourable genes or introduce beneficial components. Although not based on gene-therapy, the case of the CCR5- $\Delta 32$ stem-cell transplanted individual referred to above, points towards the potential feasibility of such approaches.

\section{Acknowledgments}

Financial support: Supported in part by the Red de Investigación de Sida (RIS) (RD06/04). Instituto de Salud Carlos III, Madrid, Spain and HIVACAT.

Potential conflict of interest: None.

\section{References}

[1] UNAIDS. 2008. Report on the global HIV/AIDS epidemic. In.

[2] Watkins, K. 2005. Human Development Report (UNDP). In United Nations Development Program.

[3] S.P. Buchbinder, M.H. Katz, N.A. Hessol, P.M. O’Malley and S.D. Holmberg, Long-term HIV-1 infection without immunologic progression, AIDS 8 (1994), 1123-1128.

[4] M.R. Betts, D.R. Ambrozak, D.C. Douek, S. Bonhoeffer, J.M. Brenchley, J.P. Casazza, R.A. Koup and L.J. Picker, Analysis of total human immunodeficiency virus (HIV)specific CD4(+) and CD8(+) T-cell responses: relationship to viral load in untreated HIV infection, J Virol 75 (2001), 11983-11991.

[5] F. Pereyra, M.M. Addo, D.E. Kaufmann, Y. Liu, T. Miura, A. Rathod, B. Baker, A. Trocha, R. Rosenberg, E. Mackey, P. Ueda, Z. Lu, D. Cohen, T. Wrin, C.J. Petropoulos, E.S. Rosenberg and B.D. Walker, Genetic and immunologic heterogeneity among persons who control HIV infection in the absence of therapy, J Infect Dis 197 (2008), 563-571.

[6] S. Rowland-Jones, J. Sutton, K. Ariyoshi, T. Dong, F. Gotch, S. McAdam, D. Whitby, S. Sabally, A. Gallimore, T. Corrah et al., HIV-specific cytotoxic T-cells in HIV-exposed but uninfected Gambian women, Nat Med 1 (1995), 59-64.

[7] J.M. McNicholl and N. Promadej, 2004. Insights into the role of host genetic and T-cell factors in resistance to HIV transmission from studies of highly HIV-exposed Thais, Immunol Res 29 (1995), 161-174.

[8] Y. Wang, X. Wang, J. Peng, L. Chen, J. Cheng, S. Nie, T. Feng, G. Zhao, J. Zhao and X. Shi, Short communication: SDF1-3' A gene mutation is correlated with increased susceptibility to HIV type 1 infection by sexual transmission in Han Chinese, AIDS Res Hum Retroviruses 24 (2008), 1341-1345.

[9] T. Hirbod, K. Broliden and R. Kaul, Genital immunoglobulin A and HIV-1 protection: virus neutralization versus specificity, AIDS 22 (2008), 2401-2402.

[10] T. Hirbod, R. Kaul, C. Reichard, J. Kimani, E. Ngugi, J.J. Bwayo, N. Nagelkerke, K. Hasselrot, B. Li, S. Moses, K.S. MacDonald and K. Broliden, HIV-neutralizing immunoglobulin A and HIV-specific proliferation are independently associated with reduced HIV acquisition in Kenyan sex workers, AIDS 22 (2008), 727-735.

[11] R. Kaul, T. Dong, F.A. Plummer, J. Kimani, T. Rostron, P. Kiama, E. Njagi, E. Irungu, B. Farah, J. Oyugi, R. Chakraborty, K.S. MacDonald, J.J. Bwayo, A. McMichael and S.L. Rowland-Jones, 2001. CD8(+) lymphocytes respond to different HIV epitopes in seronegative and infected subjects, J Clin Invest 107 (2008), 1303-1310.

[12] K. Broliden, J. Hinkula, C. Devito, P. Kiama, J. Kimani, D. Trabbatoni, J.J. Bwayo, M. Clerici, F. Plummer and R. Kaul, 2001. Functional HIV-1 specific IgA antibodies in HIV-1 exposed, persistently IgG seronegative female sex workers, Immunol Lett 79 (2008), 29-36. 
[13] S.L. Rowland-Jones, S. Pinheiro, R. Kaul, P. Hansasuta, G. Gillespie, T. Dong, F.A. Plummer, J.B. Bwayo, S. Fidler, J. Weber, A. McMichael and V. Appay, How important is the 'quality' of the cytotoxic T lymphocyte (CTL) response in protection against HIV infection? Immunol Lett 79 (2001), 15-20.

[14] R.E. Horton, T.B. Ball, C. Wachichi, W. Jaoko, W.J. Rutherford, L. McKinnon, R. Kaul, A. Rebbapragada, J. Kimani and F.A. Plummer, Cervical HIV-specific IgA in a population of commercial sex workers correlates with repeated exposure but not resistance to HIV, AIDS Res Hum Retroviruses 25 (2009), 83-92.

[15] A. Suy, P. Castro, M. Nomdedeu, F. Garcia, A. Lopez, E. Fumero, T. Gallart, L. Lopalco, O. Coll, J.M. Gatell and M. Plana, Immunological profile of heterosexual highly HIVexposed uninfected individuals: predominant role of CD4 and CD8 T-cell activation, J Infect Dis 196 (2007), 11911201.

[16] Y. Cao, L. Qin, L. Zhang, J. Safrit and D.D. Ho, Virologic and immunologic characterization of long-term survivors of human immunodeficiency virus type 1 infection, $N$ Engl $J$ Med 332 (1995), 201-208.

[17] B. Joos, M. Fischer, H. Kuster, S.K. Pillai, J.K. Wong, J. Boni, B. Hirschel, R. Weber, A. Trkola and H.F. Gunthard, HIV rebounds from latently infected cells, rather than from continuing low-level replication, Proc Natl Acad Sci U S A 105 (2008), 16725-16730.

[18] N.J. Deacon, A. Tsykin, A. Solomon, K. Smith, M. LudfordMenting, D.J. Hooker, D.A. McPhee, A.L. Greenway, A. Ellett, C. Chatfield, V.A. Lawson, S. Crowe, A. Maerz, S. Sonza, J. Learmont, J.S. Sullivan, A. Cunningham, D. Dwyer, D. Dowton and J. Mills, Genomic structure of an attenuated quasi species of HIV-1 from a blood transfusion donor and recipients, Science 270 (1995), 988-991.

[19] O. Schwartz, V. Marechal, S. Le Gall, F. Lemonnier and J.M. Heard, Endocytosis of major histocompatibility complex class I molecules is induced by the HIV-1 Nef protein, Nat Med 2 (1996), 338-342.

[20] M.J. Churchill, D.I. Rhodes, J.C. Learmont, J.S. Sullivan, S.L. Wesselingh, I.R. Cooke, N.J. Deacon and P.R. Gorry, Longitudinal analysis of human immunodeficiency virus type 1 nef/long terminal repeat sequences in a cohort of long-term survivors infected from a single source, J Virol 80 (2006), 1047-1052.

[21] L. Alexander, E. Weiskopf, T.C. Greenough, N.C. Gaddis, M.R. Auerbach, M.H. Malim, S.J. O’Brien, B.D. Walker, J.L. Sullivan and R.C. Desrosiers, Unusual polymorphisms in human immunodeficiency virus type 1 associated with nonprogressive infection, J Virol 74 (2000), 4361-4376.

[22] A.K. Iversen, E.G. Shpaer, A.G. Rodrigo, M.S. Hirsch, B.D. Walker, H.W. Sheppard, T.C. Merigan and J.I. Mullins, Persistence of attenuated rev genes in a human immunodeficiency virus type 1-infected asymptomatic individual, J Virol 69 (1995), 5743-5753.

[23] H. Hatano, E.L. Delwart, P.J. Norris, T.H. Lee, J. DunnWilliams, P.W. Hunt, R. Hoh, S.L. Stramer, J.M. Linnen, J.M. McCune, J.N. Martin, M.P. Busch and S.G. Deeks, Evidence for persistent low-level viremia in individuals who control human immunodeficiency virus in the absence of antiretroviral therapy, J Virol 83 (2009), 329-335.

[24] T. Miura, M.A. Brockman, C.J. Brumme, Z.L. Brumme, J.M. Carlson, F. Pereyra, A. Trocha, M.M. Addo, B.L. Block, A.C. Rothchild, B.M. Baker, T. Flynn, A. Schneidewind, B. Li, Y.E. Wang, D. Heckerman, T.M. Allen and B.D. Walker,
Genetic characterization of human immunodeficiency virus type 1 in elite controllers: lack of gross genetic defects or common amino acid changes, J Virol 82 (2008), 8422-8430.

[25] A. Lamine, A. Caumont-Sarcos, M.L. Chaix, A. Saez-Cirion, C. Rouzioux, J.F. Delfraissy, G. Pancino and O. Lambotte, Replication-competent HIV strains infect HIV controllers despite undetectable viremia (ANRS EP36 study), AIDS 21 (2007), 1043-1045.

[26] J. Fellay, K.V. Shianna, D. Ge, S. Colombo, B. Ledergerber, M. Weale, K. Zhang, C. Gumbs, A. Castagna, A. Cossarizza, A. Cozzi-Lepri, A. De Luca, P. Easterbrook, P. Francioli, S. Mallal, J. Martinez-Picado, J.M. Miro, N. Obel, J.P. Smith, J. Wyniger, P. Descombes, S.E. Antonarakis, N.L. Letvin, A.J. McMichael, B.F. Haynes, A. Telenti and D.B. Goldstein, A whole-genome association study of major determinants for host control of HIV-1, Science 317 (2007), 944-947.

[27] N. Frahm, P. Kiepiela, S. Adams, C.H. Linde, H.S. Hewitt, K. Sango, M.E. Feeney, M.M. Addo, M. Lichterfeld, M.P. Lahaie, E. Pae, A.G. Wurcel, T. Roach, M.A. St John, M. Altfeld, F.M. Marincola, C. Moore, S. Mallal, M. Carrington, D. Heckerman, T.M. Allen, J.I. Mullins, B.T. Korber, P.J. Goulder, B.D. Walker and C. Brander, Control of human immunodeficiency virus replication by cytotoxic T lymphocytes targeting subdominant epitopes, Nat Immunol 7 (2006), 173-178.

[28] Y. Kawashima, K. Pfafferott, J. Frater, P. Matthews, R. Payne, M. Addo, H. Gatanaga, M. Fujiwara, A. Hachiya, H. Koizumi, N. Kuse, S. Oka, A. Duda, A. Prendergast, H. Crawford, A. Leslie, Z. Brumme, C. Brumme, T. Allen, C. Brander, R. Kaslow, J. Tang, E. Hunter, S. Allen, J. Mulenga, S. Branch, T. Roach, M. John, S. Mallal, A. Ogwu, R. Shapiro, J.G. Prado, S. Fidler, J. Weber, O.G. Pybus, P. Klenerman, T. Ndung'u, R. Phillips, D. Heckerman, P.R. Harrigan, B.D. Walker, M. Takiguchi and P. Goulder, Adaptation of HIV-1 to human leukocyte antigen class I, Nature (2009).

[29] J. Dalmau, M.C. Puertas, M. Azuara, A. Marino, N. Frahm, B. Mothe, N. Izquierdo-Useros, M.J. Buzon, R. Paredes, L. Matas, T.M. Allen, C. Brander, C. Rodrigo, B. Clotet and J. Martinez-Picado, Contribution of immunological and virological factors to extremely severe primary HIV type 1 infection, Clin Infect Dis 48 (2009), 229-238.

[30] R.M. Single, M.P. Martin, X. Gao, D. Meyer, M. Yeager, J.R. Kidd, K.K. Kidd and M. Carrington, Global diversity and evidence for coevolution of KIR and HLA, Nat Genet 39 (2007), 1114-1119.

[31] P. Kiepiela, A.J. Leslie, I. Honeyborne, D. Ramduth, C. Thobakgale, S. Chetty, P. Rathnavalu, C. Moore, K.J. Pfafferott, L. Hilton, P. Zimbwa, S. Moore, T. Allen, C. Brander, M.M. Addo, M. Altfeld, I. James, S. Mallal, M. Bunce, L.D. Barber, J. Szinger, C. Day, P. Klenerman, J. Mullins, B. Korber, H.M. Coovadia, B.D. Walker and P.J. Goulder, Dominant influence of HLA-B in mediating the potential co-evolution of HIV and HLA, Nature 432 (2004), 769-775.

[32] A. Sette and J. Sidney, Nine major HLA class I supertypes account for the vast preponderance of HLA-A and -B polymorphism, Immunogenetics 50 (1999), 201-212.

[33] J. Sidney, B. Peters, N. Frahm, C. Brander and A. Sette, HLA class I supertypes: a revised and updated classification, $B M C$ Immunol 9(1) (2008).

[34] N. Frahm, S. Adams, P. Kiepiela, C.H. Linde, H.S. Hewitt, M. Lichterfeld, K. Sango, N.V. Brown, E. Pae, A.G. Wurcel, M. Altfeld, M.E. Feeney, T.M. Allen, T. Roach, M.A. St John, E.S. Daar, E. Rosenberg, B. Korber, F. Marincola, B.D. Walker, P.J. Goulder and C. Brander, HLA-B63 presents HLA- 
B57/B58-restricted cytotoxic T-lymphocyte epitopes and is associated with low human immunodeficiency virus load, $J$ Virol 79 (2005), 10218-10225.

[35] K.C. Ngumbela, C.L. Day, Z. Mncube, K. Nair, D. Ramduth, C. Thobakgale, E. Moodley, S. Reddy, C. de Pierres, N. Mkhwanazi, K. Bishop, M. van der Stok, N. Ismail, I. Honeyborne, H. Crawford, D.G. Kavanagh, C. Rousseau, D. Nickle, J. Mullins, D. Heckerman, B. Korber, H. Coovadia, P. Kiepiela, P.J. Goulder and B.D. Walker, Targeting of a CD8 T cell env epitope presented by HLA-B*5802 is associated with markers of HIV disease progression and lack of selection pressure, AIDS Res Hum Retroviruses 24 (2008), $72-82$.

[36] X. Gao, G.W. Nelson, P. Karacki, M.P. Martin, J. Phair, R. Kaslow, J.J. Goedert, S. Buchbinder, K. Hoots, D. Vlahov, S.J. O'Brien and M. Carrington, Effect of a single amino acid change in MHC class I molecules on the rate of progression to AIDS, N Engl J Med 344 (2001), 1668-1675.

[37] E. Trachtenberg, B. Korber, C. Sollars, T.B. Kepler, P.T. Hraber, E. Hayes, R. Funkhouser, M. Fugate, J. Theiler, Y.S. Hsu, K. Kunstman, S. Wu, J. Phair, H. Erlich and S. Wolinsky, Advantage of rare HLA supertype in HIV disease progression, Nat Med 9 (2003), 928-935.

[38] M. Carrington, G.W. Nelson, M.P. Martin, T. Kissner, D. Vlahov, J.J. Goedert, R. Kaslow, S. Buchbinder, K. Hoots and S.J. O'Brien, 1999. HLA and HIV-1: heterozygote advantage and B*35-Cw*04 disadvantage, Science 283 (2003), 17481752 .

[39] J. Tang, C. Costello, I.P. Keet, C. Rivers, S. Leblanc, E. Karita, S. Allen and R.A. Kaslow, HLA class I homozygosity accelerates disease progression in human immunodeficiency virus type 1 infection, AIDS Res Hum Retroviruses 15 (1999), 317-324.

[40] P. Hraber, C. Kuiken and K. Yusim, Evidence for human leukocyte antigen heterozygote advantage against hepatitis $\mathrm{C}$ virus infection, Hepatology 46 (2007), 1713-1721.

[41] K.S. MacDonald, K.R. Fowke, J. Kimani, V.A. Dunand, N.J. Nagelkerke, T.B. Ball, J. Oyugi, E. Njagi, L.K. Gaur, R.C. Brunham, J. Wade, M.A. Luscher, P. Krausa, S. RowlandJones, E. Ngugi, J.J. Bwayo and F.A. Plummer, Influence of HLA supertypes on susceptibility and resistance to human immunodeficiency virus type 1 infection, J Infect Dis 181 (2000), 1581-1589.

[42] F.A. Koning, C.A. Jansen, J. Dekker, R.A. Kaslow, N. Dukers, D. van Baarle, M. Prins and H. Schuitemaker, Correlates of resistance to HIV-1 infection in homosexual men with high-risk sexual behaviour, AIDS 18 (2004), 1117-1126.

[43] S. Boulet, M. Kleyman, J.Y. Kim, P. Kamya, S. Sharafi, N. Simic, J. Bruneau, J.P. Routy, C.M. Tsoukas and N.F. Bernard, A combined genotype of KIR3DL1 high expressing alleles and HLA-B*57 is associated with a reduced risk of HIV infection, AIDS 22 (2008), 1487-1491.

[44] T. Ndung'u, S. Gaseitsiwe, E. Sepako, F. Doualla-Bell, T. Peter, S. Kim, I. Thior, V.A. Novitsky and M. Essex, Major histocompatibility complex class II (HLA-DRB and -DQB) allele frequencies in Botswana: association with human immunodeficiency virus type 1 infection, Clin Diagn Lab Immunol 12 (2005), 1020-1028.

[45] U. Malhotra, S. Holte, S. Dutta, M.M. Berrey, E. Delpit, D.M. Koelle, A. Sette, L. Corey and M.J. McElrath, Role for HLA class II molecules in HIV-1 suppression and cellular immunity following antiretroviral treatment, J Clin Invest 107 (2001), 505-517.

[46] A. Vyakarnam, D. Sidebottom, S. Murad, J.A. Underhill, P.J.
Easterbrook, A.G. Dalgleish and M. Peakman, Possession of human leucocyte antigen DQ6 alleles and the rate of CD4 T-cell decline in human immunodeficiency virus-1 infection, Immunology 112 (2004), 136-142.

[47] H. Hendel, S. Caillat-Zucman, H. Lebuanec, M. Carrington, S. O’Brien, J.M. Andrieu, F. Schachter, D. Zagury, J. Rappaport, C. Winkler, G.W. Nelson and J.F. Zagury, New class I and II HLA alleles strongly associated with opposite patterns of progression to AIDS, J Immunol 162 (1999), 6942-6946.

[48] O. Lambotte, F. Boufassa, Y. Madec, A. Nguyen, C. Goujard, L. Meyer, C. Rouzioux, A. Venet and J.F. Delfraissy, HIV controllers: a homogeneous group of HIV-1-infected patients with spontaneous control of viral replication, Clin Infect Dis 41 (2005), 1053-1056.

[49] S.J. O'Brien, X. Gao and M. Carrington, HLA and AIDS: a cautionary tale, Trends Mol Med 7 (2001), 379-381.

[50] P. Kiepiela, K. Ngumbela, C. Thobakgale, D. Ramduth, I. Honeyborne, E. Moodley, S. Reddy, C. de Pierres, Z. Mncube, N. Mkhwanazi, K. Bishop, M. van der Stok, K. Nair, N. Khan, H. Crawford, R. Payne, A. Leslie, J. Prado, A. Prendergast, J. Frater, N. McCarthy, C. Brander, G.H. Learn, D. Nickle, C. Rousseau, H. Coovadia, J.I. Mullins, D. Heckerman, B.D. Walker and P. Goulder, CD8+ T-cell responses to different HIV proteins have discordant associations with viral load, Nat Med 13 (2007), 46-53.

[51] M. Carrington and S.J. O'Brien, The influence of HLA genotype on AIDS, Annu Rev Med 54 (2003), 535-551.

[52] P.J. Goulder, M. Bunce, P. Krausa, K. McIntyre, S. Crowley, B. Morgan, A. Edwards, P. Giangrande, R.E. Phillips and A.J. McMichael, 1996. Novel, cross-restricted, conserved, and immunodominant cytotoxic T lymphocyte epitopes in slow progressors in HIV type 1 infection, AIDS Res Hum Retroviruses 12 (2003), 1691-1698.

[53] S.A. Migueles, M.S. Sabbaghian, W.L. Shupert, M.P. Bettinotti, F.M. Marincola, L. Martino, C.W. Hallahan, S.M. Selig, D. Schwartz, J. Sullivan and M. Connors, HLA B*5701 is highly associated with restriction of virus replication in a subgroup of HIV-infected long term nonprogressors, Proc Natl Acad Sci U S A 97 (2000), 2709-2714.

[54] T. Miura, M.A. Brockman, A. Schneidewind, M. Lobritz, F. Pereyra, A. Rathod, B.L. Block, Z.L. Brumme, C.J. Brumme, B. Baker, A.C. Rothchild, B. Li, A. Trocha, E. Cutrell, N. Frahm, C. Brander, I. Toth, E.J. Arts, T.M. Allen and B.D. Walker, 2008. Hla-B57/B*5801 Hiv-1 Elite Controllers Select for Rare Gag Variants Associated with Reduced Viral Replication Capacity and Strong Ctl Recognition, J Virol (2000).

[55] J.G. Prado, I. Honeyborne, I. Brierley, M.C. Puertas, J. Martinez-Picado and P.J. Goulder, Functional consequences of human immunodeficiency virus escape from an HLA$\mathrm{B} * 13$-restricted CD8 + T-cell epitope in p1 Gag protein, $J$ Virol 83 (2009), 1018-1025.

[56] P.J. Goulder, R.E. Phillips, R.A. Colbert, S. McAdam, G. Ogg, M.A. Nowak, P. Giangrande, G. Luzzi, B. Morgan, A. Edwards, A.J. McMichael and S. Rowland-Jones, Late escape from an immunodominant cytotoxic T-lymphocyte response associated with progression to AIDS, Nat Med 3 (1997), 212-217.

[57] A.D. Kelleher, C. Long, E.C. Holmes, R.L. Allen, J. Wilson, C. Conlon, C. Workman, S. Shaunak, K. Olson, P. Goulder, C. Brander, G. Ogg, J.S. Sullivan, W. Dyer, I. Jones, A.J. McMichael, S. Rowland-Jones and R.E. Phillips, Clustered mutations in HIV-1 gag are consistently required for escape from HLA-B27-restricted cytotoxic T lymphocyte responses, 
J Exp Med 193 (2001), 375-386.

[58] A. Schneidewind, M.A. Brockman, J. Sidney, Y.E. Wang, H. Chen, T.J. Suscovich, B. Li, R.I. Adam, R.L. Allgaier, B.R. Mothe, T. Kuntzen, C. Oniangue-Ndza, A. Trocha, X.G. Yu, C. Brander, A. Sette, B.D. Walker and T.M. Allen, Structural and functional constraints limit options for cytotoxic T-lymphocyte escape in the immunodominant HLA-B27restricted epitope in human immunodeficiency virus type 1 capsid, J Virol 82 (2008), 5594-5605.

[59] Y.E. Wang, B. Li, J.M. Carlson, H. Streeck, A.D. Gladden, R. Goodman, A. Schneidewind, K.A. Power, I. Toth, N. Frahm, G. Alter, C. Brander, M. Carrington, B.D. Walker, M. Altfeld, D. Heckerman and T.M. Allen, Protective HLA class I alleles that restrict acute-phase CD8 + T-cell responses are associated with viral escape mutations located in highly conserved regions of human immunodeficiency virus type 1 , J Virol 83 (2009), 1845-1855.

[60] G. Alter, M.P. Martin, N. Teigen, W.H. Carr, T.J. Suscovich, A. Schneidewind, H. Streeck, M. Waring, A. Meier, C. Brander, J.D. Lifson, T.M. Allen, M. Carrington and M. Altfeld, Differential natural killer cell-mediated inhibition of HIV-1 replication based on distinct KIR/HLA subtypes, J Exp Med 204 (2007), 3027-3036.

[61] M. Carrington, S. Wang, M.P. Martin, X. Gao, M. Schiffman, J. Cheng, R. Herrero, A.C. Rodriguez, R. Kurman, R. Mortel, P. Schwartz, A. Glass and A. Hildesheim, Hierarchy of resistance to cervical neoplasia mediated by combinations of killer immunoglobulin-like receptor and human leukocyte antigen loci, J Exp Med 201 (2005), 1069-1075.

[62] M.P. Martin, X. Gao, J.H. Lee, G.W. Nelson, R. Detels, J.J. Goedert, S. Buchbinder, K. Hoots, D. Vlahov, J. Trowsdale, M. Wilson, S.J. O'Brien and M. Carrington, Epistatic interaction between KIR3DS1 and HLA-B delays the progression to AIDS, Nat Genet 31 (2002), 429-434.

[63] C.A. Muller, G. Engler-Blum, V. Gekeler, I. Steiert, E. Weiss and H. Schmidt, Genetic and serological heterogeneity of the supertypic HLA-B locus specificities Bw4 and Bw6, Immunogenetics 30 (1989), 200-207.

[64] P.O. Flores-Villanueva, E.J. Yunis, J.C. Delgado, E. Vittinghoff, S. Buchbinder, J.Y. Leung, A.M. Uglialoro, O.P. Clavijo, E.S. Rosenberg, S.A. Kalams, J.D. Braun, S.L. Boswell, B.D. Walker and A.E. Goldfeld, Control of HIV-1 viremia and protection from AIDS are associated with HLABw4 homozygosity, Proc Natl Acad Sci U S A 98 (2001), 5140-5145.

[65] J.E. Gumperz, V. Litwin, J.H. Phillips, L.L. Lanier and P. Parham, The Bw4 public epitope of HLA-B molecules confers reactivity with natural killer cell clones that express NKB1, a putative HLA receptor, J Exp Med 181 (1995), 1133-1144.

[66] M.P. Martin, Y. Qi, X. Gao, E. Yamada, J.N. Martin, F. Pereyra, S. Colombo, E.E. Brown, W.L. Shupert, J. Phair, J.J. Goedert, S. Buchbinder, G.D. Kirk, A. Telenti, M. Connors, S.J. O’Brien, B.D. Walker, P. Parham, S.G. Deeks, D.W. McVicar and M. Carrington, Innate partnership of HLA-B and KIR3DL1 subtypes against HIV-1, Nat Genet 39 (2007), 733-740.

[67] B.J. Doranz, J. Rucker, Y. Yi, R.J. Smyth, M. Samson, S.C. Peiper, M. Parmentier, R.G. Collman and R.W. Doms, A dual-tropic primary HIV-1 isolate that uses fusin and the betachemokine receptors CKR-5, CKR-3, and CKR-2b as fusion cofactors, Cell 85 (1996), 1149-1158.

[68] Y. Feng, C.C. Broder, P.E. Kennedy and E.A. Berger, HIV1 entry cofactor: functional cDNA cloning of a seven- transmembrane, G protein-coupled receptor, Science $\mathbf{2 7 2}$ (1996), 872-877.

[69] S.A. Luther and J.G. Cyster, Chemokines as regulators of T cell differentiation, Nat Immunol 2 (2001), 102-107.

[70] B. Moser and P. Loetscher, Lymphocyte traffic control by chemokines, Nat Immunol 2 (2001), 123-128.

[71] M. Baggiolini, B. Dewald and B. Moser, Human chemokines: an update, Annu Rev Immunol 15 (1997), 675-705.

[72] E.A. Berger, R.W. Doms, E.M. Fenyo, B.T. Korber, D.R. Littman, J.P. Moore, Q.J. Sattentau, H. Schuitemaker, J. Sodroski and R.A. Weiss, A new classification for HIV-1, Nature 391 (1998), 240.

[73] C.C. Bleul, M. Farzan, H. Choe, C. Parolin, I. Clark-Lewis, J. Sodroski and T.A. Springer, The lymphocyte chemoattractant SDF-1 is a ligand for LESTR/fusin and blocks HIV-1 entry, Nature 382 (1996), 829-833.

[74] F. Cocchi, A.L. DeVico, A. Garzino-Demo, S.K. Arya, R.C. Gallo and P. Lusso, Identification of RANTES, MIP-1 alpha, and MIP-1 beta as the major HIV-suppressive factors produced by CD8+ T cells, Science 270 (1995), 1811-1815.

[75] R. Horuk, Chemokine receptors and HIV-1: the fusion of two major research fields, Immunol Today 20 (1999), 89-94.

[76] O.J. Cohen, M. Vaccarezza, G.K. Lam, B.F. Baird, K. Wildt, P.M. Murphy, P.A. Zimmerman, T.B. Nutman, C.H. Fox, S. Hoover, J. Adelsberger, M. Baseler, J. Arthos, R.T. Davey, Jr., R.L. Dewar, J. Metcalf, D.J. Schwartzentruber, J.M. Orenstein, S. Buchbinder, A.J. Saah, R. Detels, J. Phair, C. Rinaldo, J.B. Margolick, G. Pantaleo and A.S. Fauci, Heterozygosity for a defective gene for $\mathrm{CC}$ chemokine receptor 5 is not the sole determinant for the immunologic and virologic phenotype of HIV-infected long-term nonprogressors, J Clin Invest 100 (1997), 1581-1589.

[77] M. Dean, M. Carrington, C. Winkler, G.A. Huttley, M.W. Smith, R. Allikmets, J.J. Goedert, S.P. Buchbinder, E. Vittinghoff, E. Gomperts, S. Donfield, D. Vlahov, R. Kaslow, A. Saah, C. Rinaldo, R. Detels and S.J. O'Brien, Genetic restriction of HIV-1 infection and progression to AIDS by a deletion allele of the CKR5 structural gene. Hemophilia Growth and Development Study, Multicenter AIDS Cohort Study, Multicenter Hemophilia Cohort Study, San Francisco City Cohort, ALIVE Study, Science 273 (1996), 1856-1862.

[78] R. Liu, W.A. Paxton, S. Choe, D. Ceradini, S.R. Martin, R. Horuk, M.E. MacDonald, H. Stuhlmann, R.A. Koup and N.R. Landau, Homozygous defect in HIV-1 coreceptor accounts for resistance of some multiply-exposed individuals to HIV-1 infection, Cell 86 (1996), 367-377.

[79] J. Rappaport, Y.Y. Cho, H. Hendel, E.J. Schwartz, F. Schachter and J.F. Zagury, 32 bp CCR-5 gene deletion and resistance to fast progression in HIV-1 infected heterozygotes, Lancet 349 (1997), 922-923.

[80] D.H. McDermott, P.A. Zimmerman, F. Guignard, C.A. Kleeberger, S.F. Leitman and P.M. Murphy, CCR5 promoter polymorphism and HIV-1 disease progression. Multicenter AIDS Cohort Study (MACS), Lancet 352 (1998), 866-870.

[81] N.L. Michael, L.G. Louie, A.L. Rohrbaugh, K.A. Schultz, D.E. Dayhoff, C.E. Wang and H.W. Sheppard, The role of CCR5 and CCR2 polymorphisms in HIV-1 transmission and disease progression, Nat Med 3 (1997), 1160-1162.

[82] L.G. Kostrikis, Y. Huang, J.P. Moore, S.M. Wolinsky, L. Zhang, Y. Guo, L. Deutsch, J. Phair, A.U. Neumann and D.D. Ho, A chemokine receptor CCR2 allele delays HIV-1 disease progression and is associated with a CCR5 promoter mutation, Nat Med 4 (1998), 350-353.

[83] M.W. Smith, M. Dean, M. Carrington, C. Winkler, G.A. Hutt- 
ley, D.A. Lomb, J.J. Goedert, T.R. O'Brien, L.P. Jacobson, R. Kaslow, S. Buchbinder, E. Vittinghoff, D. Vlahov, K. Hoots, M.W. Hilgartner and S.J. O'Brien, Contrasting genetic influence of CCR2 and CCR5 variants on HIV-1 infection and disease progression. Hemophilia Growth and Development Study (HGDS), Multicenter AIDS Cohort Study (MACS), Multicenter Hemophilia Cohort Study (MHCS), San Francisco City Cohort (SFCC), ALIVE Study, Science 277 (1997), 959-965.

[84] S.A. Mulherin, T.R. O'Brien, J.P. Ioannidis, J.J. Goedert, S.P Buchbinder, R.A. Coutinho, B.D. Jamieson, L. Meyer, N.L. Michael, G. Pantaleo, G.P. Rizzardi, H. Schuitemaker, H.W. Sheppard, I.D. Theodorou, D. Vlahov and P.S. Rosenberg, Effects of CCR5-Delta32 and CCR2-64I alleles on HIV-1 disease progression: the protection varies with duration of infection, AIDS 17 (2003), 377-387.

[85] R.M. Gulick, J. Lalezari, J. Goodrich, N. Clumeck, E. DeJesus, A. Horban, J. Nadler, B. Clotet, A. Karlsson, M. Wohlfeiler, J.B. Montana, M. McHale, J. Sullivan, C. Ridgway, S. Felstead, M.W. Dunne, E. van der Ryst and H. Mayer, Maraviroc for previously treated patients with R5 HIV-1 infection, N Engl J Med 359 (2008), 1429-1441.

[86] R.J. Landovitz, J.B. Angel, C. Hoffmann, H. Horst, M. Opravil, J. Long, W. Greaves and G. Fatkenheuer, Phase II study of vicriviroc versus efavirenz (both with zidovudine/lamivudine) in treatment-naive subjects with HIV-1 infection, J Infect Dis 198 (2008), 1113-1122.

[87] G. Hutter, D. Nowak, M. Mossner, S. Ganepola, A. Mussig, K. Allers, T. Schneider, J. Hofmann, C. Kucherer, O. Blau, I.W. Blau, W.K. Hofmann and E. Thiel, Long-term control of HIV by CCR5 Delta32/Delta32 stem-cell transplantation, N Engl J Med 360 (2009), 692-698.

[88] C.A. Derdeyn, C. Costello, J.M. Kilby, G. Sfakianos, M.S. Saag, R. Kaslow and R.P. Bucy, Correlation between circulating stromal cell-derived factor 1 levels and CD4+ cell count in human immunodeficiency virus type 1-infected individuals, AIDS Res Hum Retroviruses 15 (1999), 1063-1071.

[89] H. Liu, D. Chao, E.E. Nakayama, H. Taguchi, M. Goto, X. Xin, J.K. Takamatsu, H. Saito, Y. Ishikawa, T. Akaza, T. Juji, Y. Takebe, T. Ohishi, K. Fukutake, Y. Maruyama, S. Yashiki, S. Sonoda, T. Nakamura, Y. Nagai, A. Iwamoto and T. Shioda, Polymorphism in RANTES chemokine promoter affects HIV-1 disease progression, Proc Natl Acad Sci U S A 96 (1999), 4581-4585.

[90] D.H. McDermott, M.J. Beecroft, C.A. Kleeberger, F.M. AlSharif, W.E. Ollier, P.A. Zimmerman, B.A. Boatin, S.F. Leitman, R. Detels, A.H. Hajeer and P.M. Murphy, Chemokine RANTES promoter polymorphism affects risk of both HIV infection and disease progression in the Multicenter AIDS Cohort Study, AIDS 14 (2000), 2671-2678.

[91] A. Brambilla, C. Villa, G. Rizzardi, F. Veglia, S. Ghezzi, A. Lazzarin, M. Cusini, S. Muratori, E. Santagostino, A. Gringeri, L.G. Louie, H.W. Sheppard, G. Poli, N.L. Michael, G. Pantaleo and E. Vicenzi, Shorter survival of SDF13'A/3'A homozygotes linked to CD4 $+\mathrm{T}$ cell decrease in advanced human immunodeficiency virus type 1 infection, $J$ Infect Dis 182 (2000), 311-315.

[92] O. Chaudhary, K. Rajsekar, I. Ahmed, R. Verma, M. Bala, R. Bhasin and K. Luthra, Polymorphic variants in DC-SIGN, DC-SIGNR and SDF-1 in high risk seronegative and HIV-1 patients in Northern Asian Indians, J Clin Virol 43 (2008), 196-201.

[93] H. Liu, Y. Hwangbo, S. Holte, J. Lee, C. Wang, N. Kaupp, H. Zhu, C. Celum, L. Corey, M.J. McElrath and T. Zhu,
Analysis of genetic polymorphisms in CCR5, CCR2, stromal cell-derived factor-1, RANTES, and dendritic cell-specific intercellular adhesion molecule-3-grabbing nonintegrin in seronegative individuals repeatedly exposed to HIV-1, J Infect Dis 190 (2004), 1055-1058.

[94] C. Winkler, W. Modi, M.W. Smith, G.W. Nelson, X. Wu, M. Carrington, M. Dean, T. Honjo, K. Tashiro, D. Yabe, S. Buchbinder, E. Vittinghoff, J.J. Goedert, T.R. O'Brien, L.P. Jacobson, R. Detels, S. Donfield, A. Willoughby, E. Gomperts, D. Vlahov, J. Phair and S.J. O'Brien, Genetic restriction of AIDS pathogenesis by an SDF-1 chemokine gene variant. ALIVE Study, Hemophilia Growth and Development Study (HGDS), Multicenter AIDS Cohort Study (MACS), Multicenter Hemophilia Cohort Study (MHCS), San Francisco City Cohort (SFCC), Science 279 (1998), 389-393.

[95] T. Nagasawa, Role of chemokine SDF-1/PBSF and its receptor CXCR4 in blood vessel development, Ann N Y Acad Sci 947 (2001), 112-115; discussion 115-116.

[96] E. Gonzalez, H. Kulkarni, H. Bolivar, A. Mangano, R. Sanchez, G. Catano, R.J. Nibbs, B.I. Freedman, M.P. Quinones, M.J. Bamshad, K.K. Murthy, B.H. Rovin, W. Bradley, R.A. Clark, S.A. Anderson, J. O'Connell R, B.K. Agan, S.S. Ahuja, R. Bologna, L. Sen, M.J. Dolan and S.K. Ahuja, The influence of CCL3L1 gene-containing segmental duplications on HIV-1/AIDS susceptibility, Science $\mathbf{3 0 7}$ (2005), 1434-1440.

[97] M.P. Martin, M.M. Lederman, H.B. Hutcheson, J.J. Goedert, G.W. Nelson, Y. van Kooyk, R. Detels, S. Buchbinder, K. Hoots, D. Vlahov, S.J. O’Brien and M. Carrington, Association of DC-SIGN promoter polymorphism with increased risk for parenteral, but not mucosal, acquisition of human immunodeficiency virus type 1 infection, J Virol 78 (2004), 14053-14056.

[98] P. Selvaraj, K. Alagarasu, S. Swaminathan, M. Harishankar and G. Narendran, CD209 gene polymorphisms in South Indian HIV and HIV-TB patients, Infect Genet Evol 9 (2009), 256-262.

[99] R.A. Koup and D.D. Ho, Shutting down HIV, Nature 370 (1994), 416.

[100] G. Pantaleo, J.F. Demarest, T. Schacker, M. Vaccarezza, O.J. Cohen, M. Daucher, C. Graziosi, S.S. Schnittman, T.C. Quinn, G.M. Shaw, L. Perrin, G. Tambussi, A. Lazzarin, R.P. Sekaly, H. Soudeyns, L. Corey and A.S. Fauci, The qualitative nature of the primary immune response to HIV infection is a prognosticator of disease progression independent of the initial level of plasma viremia, Proc Natl Acad Sci U S A 94 (1997), 254-258.

[101] T.C. Friedrich, L.E. Valentine, L.J. Yant, E.G. Rakasz, S.M. Piaskowski, J.R. Furlott, K.L. Weisgrau, B. Burwitz, G.E. May, E.J. Leon, T. Soma, G. Napoe, S.V. Capuano, 3rd, N.A. Wilson and D.I. Watkins, Subdominant CD8+ T-cell responses are involved in durable control of AIDS virus replication, J Virol 81 (2007), 3465-3476.

[102] J.E. Schmitz, M.J. Kuroda, S. Santra, V.G. Sasseville, M.A. Simon, M.A. Lifton, P. Racz, K. Tenner-Racz, M. Dalesandro, B.J. Scallon, J. Ghrayeb, M.A. Forman, D.C. Montefiori, E.P. Rieber, N.L. Letvin and K.A. Reimann, Control of viremia in simian immunodeficiency virus infection by CD8+ lymphocytes, Science 283 (1999), 857-860.

[103] J.D. Altman, P.A. Moss, P.J. Goulder, D.H. Barouch, M.G. McHeyzer-Williams, J.I. Bell, A.J. McMichael and M.M. Davis, Phenotypic analysis of antigen-specific T lymphocytes, Science 274 (1996), 94-96.

[104] P.J. Goulder, Y. Tang, C. Brander, M.R. Betts, M. Altfeld, K. 
Annamalai, A. Trocha, S. He, E.S. Rosenberg, G. Ogg, C.A. O'Callaghan, S.A. Kalams, R.E. McKinney, Jr., K. Mayer, R.A. Koup, S.I. Pelton, S.K. Burchett, K. McIntosh and B.D. Walker, Functionally inert HIV-specific cytotoxic T lymphocytes do not play a major role in chronically infected adults and children, J Exp Med 192 (2000), 1819-1832.

[105] G.S. Ogg, X. Jin, S. Bonhoeffer, P.R. Dunbar, M.A. Nowak, S. Monard, J.P. Segal, Y. Cao, S.L. Rowland-Jones, V. Cerundolo, A. Hurley, M. Markowitz, D.D. Ho, D.F. Nixon and A.J. McMichael, Quantitation of HIV-1-specific cytotoxic T lymphocytes and plasma load of viral RNA, Science 279 (1998), 2103-2106.

[106] C. Brander, K.E. Hartman, A.K. Trocha, N.G. Jones, R.P. Johnson, B. Korber, P. Wentworth, S.P. Buchbinder, S. Wolinsky, B.D. Walker and S.A. Kalams, Lack of strong immune selection pressure by the immunodominant, HLA-A*0201restricted cytotoxic $\mathrm{T}$ lymphocyte response in chronic human immunodeficiency virus-1 infection, J Clin Invest 101 (1998), 2559-2566.

[107] O.O. Yang, S.A. Kalams, M. Rosenzweig, A. Trocha, N. Jones, M. Koziel, B.D. Walker and R.P. Johnson, Efficient lysis of human immunodeficiency virus type 1-infected cells by cytotoxic T lymphocytes, J Virol 70 (1996), 5799-5806.

[108] O.O. Yang, S.A. Kalams, A. Trocha, H. Cao, A. Luster, R.P Johnson and B.D. Walker, Suppression of human immunodeficiency virus type 1 replication by CD8+ cells: evidence for HLA class I-restricted triggering of cytolytic and noncytolytic mechanisms, J Virol 71 (1997), 3120-3128.

[109] N. Frahm, B.T. Korber, C.M. Adams, J.J. Szinger, R. Draenert, M.M. Addo, M.E. Feeney, K. Yusim, K. Sango, N.V. Brown, D. SenGupta, A. Piechocka-Trocha, T. Simonis, F.M. Marincola, A.G. Wurcel, D.R. Stone, C.J. Russell, P. Adolf, D. Cohen, T. Roach, A. StJohn, A. Khatri, K. Davis, J. Mullins, P.J. Goulder, B.D. Walker and C. Brander, Consistent cytotoxic-T-lymphocyte targeting of immunodominant regions in human immunodeficiency virus across multiple ethnicities, J Virol 78 (2004), 2187-2200.

[110] A. Saez-Cirion, C. Lacabaratz, O. Lambotte, P. Versmisse, A. Urrutia, F. Boufassa, F. Barre-Sinoussi, J.F. Delfraissy, M. Sinet, G. Pancino and A. Venet, HIV controllers exhibit potent CD8 T cell capacity to suppress HIV infection ex vivo and peculiar cytotoxic T lymphocyte activation phenotype, Proc Natl Acad Sci U S A 104 (2007), 6776-6781.

[111] C. Brander, N. Frahm and B.D. Walker, 2006. The challenges of host and viral diversity in HIV vaccine design, Curr Opin Immunol 18 (2007), 430-437.

[112] R. Zuniga, A. Lucchetti, P. Galvan, S. Sanchez, C. Sanchez, A. Hernandez, H. Sanchez, N. Frahm, C.H. Linde, H.S. Hewitt, W. Hildebrand, M. Altfeld, T.M. Allen, B.D. Walker, B.T. Korber, T. Leitner, J. Sanchez and C. Brander, Relative dominance of Gag p24-specific cytotoxic T lymphocytes is associated with human immunodeficiency virus control, $J$ Virol 80 (2006), 3122-3125.

[113] M. Altfeld, E.T. Kalife, Y. Qi, H. Streeck, M. Lichterfeld, M.N. Johnston, N. Burgett, M.E. Swartz, A. Yang, G. Alter, X.G. Yu, A. Meier, J.K. Rockstroh, T.M. Allen, H. Jessen, E.S. Rosenberg, M. Carrington and B.D. Walker, HLA Alleles Associated with Delayed Progression to AIDS Contribute Strongly to the Initial CD8(+) T Cell Response against HIV1, PLoS Med 3 (2006), e 403.

[114] B.H. Edwards, A. Bansal, S. Sabbaj, J. Bakari, M.J. Mulligan and P.A. Goepfert, Magnitude of functional CD8+ T-cell responses to the gag protein of human immunodeficiency virus type 1 correlates inversely with viral load in plasma, $J$
Virol 76 (2002), 2298-2305.

[115] I. Honeyborne, A. Prendergast, F. Pereyra, A. Leslie, H. Crawford, R. Payne, S. Reddy, K. Bishop, E. Moodley, K. Nair, M. van der Stok, N. McCarthy, C.M. Rousseau, M. Addo, J.I. Mullins, C. Brander, P. Kiepiela, B.D. Walker and P.J. Goulder, Control of human immunodeficiency virus type 1 is associated with HLA-B*13 and targeting of multiple gag-specific CD8+ T-cell epitopes, J Virol 81 (2007), 36673672 .

[116] A. Masemola, T. Mashishi, G. Khoury, P. Mohube, P. Mokgotho, E. Vardas, M. Colvin, L. Zijenah, D. Katzenstein, R. Musonda, S. Allen, N. Kumwenda, T. Taha, G. Gray, J. McIntyre, S.A. Karim, H.W. Sheppard and C.M. Gray, Hierarchical targeting of subtype $\mathrm{C}$ human immunodeficiency virus type 1 proteins by $\mathrm{CD} 8+\mathrm{T}$ cells: correlation with viral load, J Virol 78 (2004), 3233-3243.

[117] M.L. Ndongala, Y. Peretz, S. Boulet, M. Doroudchi, B. Yassine-Diab, M.R. Boulassel, D. Rouleau, C. Tremblay, R. Leblanc, J.P. Routy, R.P. Sekaly and N.F. Bernard, HIV Gag p24 specific responses secreting IFN-gamma and/or IL-2 in treatment-naive individuals in acute infection early disease (AIED) are associated with low viral load, Clin Immunol (2009).

[118] J.B. Sacha, C. Chung, E.G. Rakasz, S.P. Spencer, A.K. Jonas, A.T. Bean, W. Lee, B.J. Burwitz, J.J. Stephany, J.T. Loffredo, D.B. Allison, S. Adnan, A. Hoji, N.A. Wilson, T.C. Friedrich, J.D. Lifson, O.O. Yang and D.I. Watkins, Gagspecific CD8+ T lymphocytes recognize infected cells before AIDS-virus integration and viral protein expression, $J$ Immunol 178 (2007), 2746-2754.

[119] M.R. Betts, M.C. Nason, S.M. West, S.C. De Rosa, S.A. Migueles, J. Abraham, M.M. Lederman, J.M. Benito, P.A. Goepfert, M. Connors, M. Roederer and R.A. Koup, HIV nonprogressors preferentially maintain highly functional HIV-specific CD8+ T cells, Blood 107 (2006), 4781-4789.

[120] S.A. Migueles, A.C. Laborico, W.L. Shupert, M.S. Sabbaghian, R. Rabin, C.W. Hallahan, D. Van Baarle, S. Kostense, F. Miedema, M. McLaughlin, L. Ehler, J. Metcalf, S. Liu and M. Connors, HIV-specific CD8 + T cell proliferation is coupled to perforin expression and is maintained in nonprogressors, Nat Immunol 3 (2002), 1061-1068.

[121] D. Yerly, D. Heckerman, T. Allen, T.J. Suscovich, N. Jojic, C. Kadie, W.J. Pichler, A. Cerny and C. Brander, Design, expression, and processing of epitomized hepatitis $\mathrm{C}$ virusencoded CTL epitopes, J Immunol 181 (2008), 6361-6370.

[122] D. Yerly, D. Heckerman, T.M. Allen, J.V. Chisholm, 3rd, K. Faircloth, C.H. Linde, N. Frahm, J. Timm, W.J. Pichler, A. Cerny and C. Brander, Increased cytotoxic T-lymphocyte epitope variant cross-recognition and functional avidity are associated with hepatitis C virus clearance, J Virol 82 (2008), 3147-3153.

[123] T.M. Allen, M. Altfeld, S.C. Geer, E.T. Kalife, C. Moore, M. O'Sullivan K, I. Desouza, M.E. Feeney, R.L. Eldridge, E.L. Maier, D.E. Kaufmann, M.P. Lahaie, L. Reyor, G. Tanzi, M.N. Johnston, C. Brander, R. Draenert, J.K. Rockstroh, H. Jessen, E.S. Rosenberg, S.A. Mallal and B.D. Walker, Selective escape from CD8+ T-cell responses represents a major driving force of human immunodeficiency virus type 1 (HIV-1) sequence diversity and reveals constraints on HIV-1 evolution, J Virol 79 (2005), 13239-13249.

[124] T.M. Allen, M. Altfeld, X.G. Yu, K.M. O’Sullivan, M. Lichterfeld, S. Le Gall, M. John, B.R. Mothe, P.K. Lee, E.T. Kalife, D.E. Cohen, K.A. Freedberg, D.A. Strick, M.N. Johnston, A. Sette, E.S. Rosenberg, S.A. Mallal, P.J. Goulder, C. 
Brander and B.D. Walker, Selection, transmission, and reversion of an antigen-processing cytotoxic T-lymphocyte escape mutation in human immunodeficiency virus type 1 infection, J Virol 78 (2004), 7069-7078.

[125] R. Draenert, S. Le Gall, K.J. Pfafferott, A.J. Leslie, P. Chetty, C. Brander, E.C. Holmes, S.C. Chang, M.E. Feeney, M.M. Addo, L. Ruiz, D. Ramduth, P. Jeena, M. Altfeld, S. Thomas, Y. Tang, C.L. Verrill, C. Dixon, J.G. Prado, P. Kiepiela, J. Martinez-Picado, B.D. Walker and P.J. Goulder, Immune selection for altered antigen processing leads to cytotoxic $\mathrm{T}$ lymphocyte escape in chronic HIV-1 infection, J Exp Med 199 (2004), 905-915.

[126] A.J. Leslie, K.J. Pfafferott, P. Chetty, R. Draenert, M.M. Addo, M. Feeney, Y. Tang, E.C. Holmes, T. Allen, J.G. Prado, M. Altfeld, C. Brander, C. Dixon, D. Ramduth, P. Jeena, S.A. Thomas, A. St John, T.A. Roach, B. Kupfer, G. Luzzi, A. Edwards, G. Taylor, H. Lyall, G. Tudor-Williams, V. Novelli, J. Martinez-Picado, P. Kiepiela, B.D. Walker and P.J. Goulder, HIV evolution: CTL escape mutation and reversion after transmission, Nat Med 10 (2004), 282-289.

[127] J. Martinez-Picado, J.G. Prado, E.E. Fry, K. Pfafferott, A. Leslie, S. Chetty, C. Thobakgale, I. Honeyborne, H. Crawford, P. Matthews, T. Pillay, C. Rousseau, J.I. Mullins, C. Brander, B.D. Walker, D.I. Stuart, P. Kiepiela and P. Goulder, Fitness cost of escape mutations in p24 Gag in association with control of human immunodeficiency virus type 1, $J$ Virol 80 (2006), 3617-3623.

[128] F.W. Peyerl, H.S. Bazick, M.H. Newberg, D.H. Barouch, J. Sodroski and N.L. Letvin, Fitness costs limit viral escape from cytotoxic $\mathrm{T}$ lymphocytes at a structurally constrained epitope, J Virol 78 (2004), 13901-13910.

[129] Z.L. Brumme, C.J. Brumme, D. Heckerman, B.T. Korber, M. Daniels, J. Carlson, C. Kadie, T. Bhattacharya, C. Chui, J. Szinger, T. Mo, R.S. Hogg, J.S. Montaner, N. Frahm, C. Brander, B.D. Walker and P.R. Harrigan, Evidence of differential HLA class I-mediated viral evolution in functional and accessory/regulatory genes of HIV-1, PLoS Pathog 3 (2007), e94.

[130] Z.L. Brumme, I. Tao, S. Szeto, C.J. Brumme, J.M. Carlson, D. Chan, C. Kadie, N. Frahm, C. Brander, B. Walker, D. Heckerman and P.R. Harrigan, Human leukocyte antigenspecific polymorphisms in HIV-1 Gag and their association with viral load in chronic untreated infection, AIDS 22 (2008), 1277-1286.

[131] S.A. Kalams, S.P. Buchbinder, E.S. Rosenberg, J.M. Billingsley, D.S. Colbert, N.G. Jones, A.K. Shea, A.K. Trocha and B.D. Walker, Association between virus-specific cytotoxic T-lymphocyte and helper responses in human immunodeficiency virus type 1 infection, J Virol 73 (1999), 6715-6720.

[132] S.A. Kalams, P.J. Goulder, A.K. Shea, N.G. Jones, A.K. Trocha, G.S. Ogg and B.D. Walker, Levels of human immunodeficiency virus type 1-specific cytotoxic T-lymphocyte effector and memory responses decline after suppression of viremia with highly active antiretroviral therapy, $J$ Virol 73 (1999), 6721-6728.

[133] M. Lichterfeld, D.E. Kaufmann, X.G. Yu, S.K. Mui, M.M. Addo, M.N. Johnston, D. Cohen, G.K. Robbins, E. Pae, G. Alter, A. Wurcel, D. Stone, E.S. Rosenberg, B.D. Walker and M. Altfeld, Loss of HIV-1-specific CD8+ T cell proliferation after acute HIV-1 infection and restoration by vaccineinduced HIV-1-specific CD4+ T cells, JExp Med 200 (2004), 701-712.

[134] O. Gasser, F.K. Bihl, M. Wolbers, E. Loggi, I. Steffen, H.H.
Hirsch, H.F. Gunthard, B.D. Walker, C. Brander, M. Battegay and C. Hess, 2007. HIV patients developing primary CNS lymphoma lack EBV-specific CD4+ T cell function irrespective of absolute CD4+ T cell counts, PLoS Med 4 (2004), e96.

[135] O. Gasser, B.F., S. Sanghavi, C. Rinaldo, D. Rowe, C. Hess, D. Stablein, M. Roland, P. Stock and C. Brander, Treatmentdependent loss of polyfunctional CD8 + T-cell responses in HIV-infected kidney transplant recipients is associated with herpesvirus reactivation, American Journal of Transplantation (2009), in press.

[136] V. Martinez, D. Costagliola, O. Bonduelle, N. N'go, A. Schnuriger, I. Theodorou, J.P. Clauvel, D. Sicard, H. Agut, P. Debre, C. Rouzioux and B. Autran, Combination of HIV1-specific CD4 Th1 cell responses and IgG2 antibodies is the best predictor for persistence of long-term nonprogression, $J$ Infect Dis 191 (2005), 2053-2063.

[137] N. Ngo-Giang-Huong, D. Candotti, A. Goubar, B. Autran, M. Maynart, D. Sicard, J.P. Clauvel, H. Agut, D. Costagliola and C. Rouzioux, 2001. HIV type 1-specific IgG2 antibodies: markers of helper T cell type 1 response and prognostic marker of long-term nonprogression, AIDS Res Hum Retroviruses 17 (2005), 1435-1446.

[138] A. Trkola, H. Kuster, P. Rusert, B. Joos, M. Fischer, C. Leemann, A. Manrique, M. Huber, M. Rehr, A. Oxenius, R. Weber, G. Stiegler, B. Vcelar, H. Katinger, L. Aceto and H.F. Gunthard, Delay of HIV-1 rebound after cessation of antiretroviral therapy through passive transfer of human neutralizing antibodies, Nat Med 11 (2005), 615-622.

[139] D.C. Montefiori, G. Pantaleo, L.M. Fink, J.T. Zhou, J.Y. Zhou, M. Bilska, G.D. Miralles and A.S. Fauci, Neutralizing and infection-enhancing antibody responses to human immunodeficiency virus type 1 in long-term nonprogressors, $J$ Infect Dis 173 (1996), 60-67.

[140] Q. Li, L. Duan, J.D. Estes, Z.M. Ma, T. Rourke, Y. Wang, C. Reilly, J. Carlis, C.J. Miller and A.T. Haase, Peak SIV replication in resting memory $\mathrm{CD} 4+\mathrm{T}$ cells depletes gut lamina propria CD4+ T cells, Nature 434 (2005), 11481152.

[141] J.J. Mattapallil, D.C. Douek, B. Hill, Y. Nishimura, M. Martin and M. Roederer, Massive infection and loss of memory CD4+ T cells in multiple tissues during acute SIV infection, Nature 434 (2005), 1093-1097.

[142] S. Mehandru, M.A. Poles, K. Tenner-Racz, A. Horowitz, A. Hurley, C. Hogan, D. Boden, P. Racz and M. Markowitz, Primary HIV-1 infection is associated with preferential depletion of CD4+ T lymphocytes from effector sites in the gastrointestinal tract, J Exp Med 200 (2004), 761-770.

[143] J.M. Brenchley, D.A. Price and D.C. Douek, HIV disease: fallout from a mucosal catastrophe? Nat Immunol 7 (2006), 235-239.

[144] C. Guarner and G. Soriano, Bacterial translocation and its consequences in patients with cirrhosis, Eur J Gastroenterol Hepatol 17 (2005), 27-31.

[145] M. Carrington, M.P. Martin and J. van Bergen, KIR-HLA intercourse in HIV disease, Trends Microbiol 16 (2008), 620627.

[146] P.Y. Bochud, M. Bochud, A. Telenti and T. Calandra, Innate immunogenetics: a tool for exploring new frontiers of host defence, Lancet Infect Dis 7 (2007), 531-542.

[147] J.C. Sun, J.N. Beilke and L.L. Lanier, Adaptive immune features of natural killer cells, Nature 457 (2009), 557-561. 


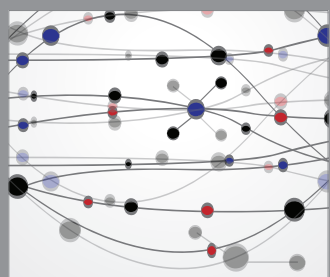

The Scientific World Journal
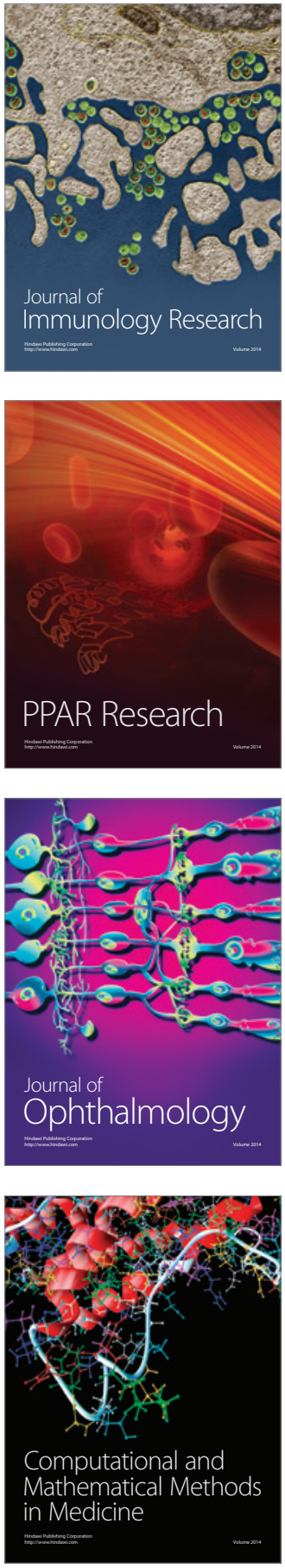

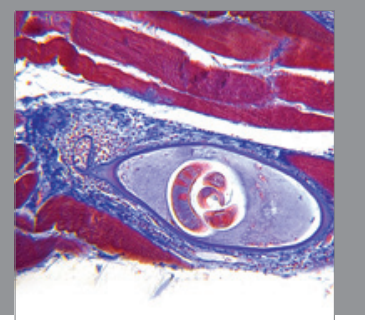

Gastroenterology

Research and Practice
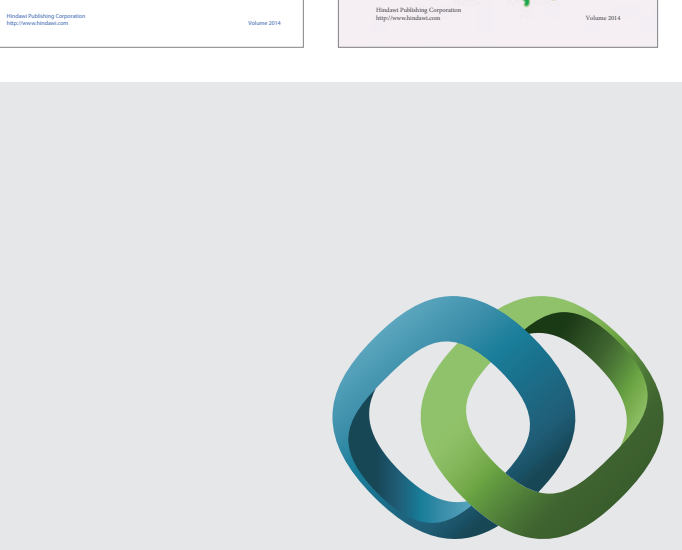

\section{Hindawi}

Submit your manuscripts at

http://www.hindawi.com
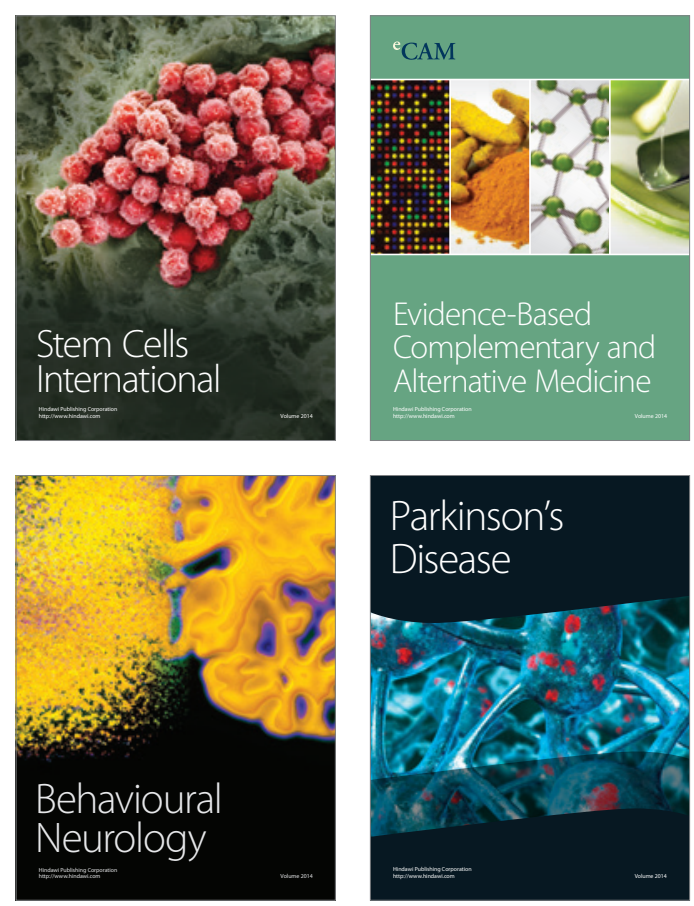

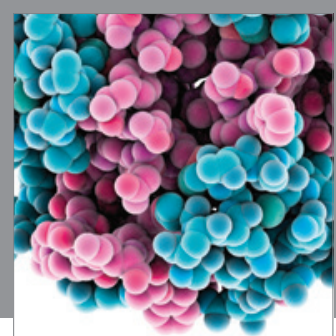

Journal of
Diabetes Research

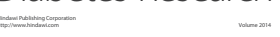

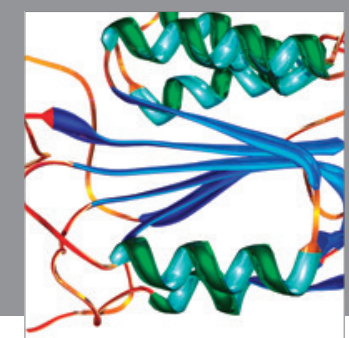

Disease Markers
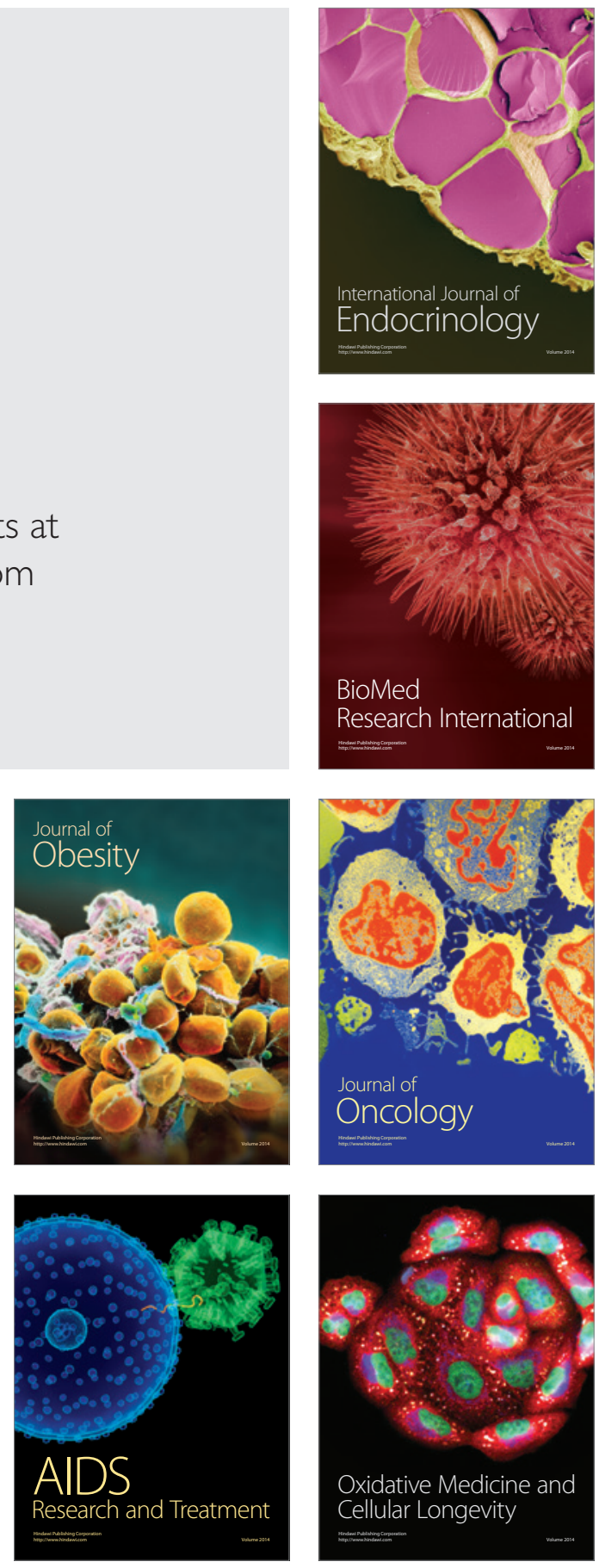